\title{
TAX OVERPAYMENTS, TAX EVASION, AND BOOK-TAX DIFFERENCES
}

\author{
LASZLO GOERKE
}

CESIFo Working PAPER No. 2212

CATEgory 1: Public FinANCE

FEBRUARY 2008

\footnotetext{
An electronic version of the paper may be downloaded

- from the SSRN website: www.SSRN.com

- from the RePEc website:

- from the CESifo website:

www.RePEc.org

www.CESifo-group.org/wp
} 


\title{
TAX OVERPAYMENTS, TAX EVASION, AND BOOK-TAX DIFFERENCES
}

\begin{abstract} tax payments and book profit declarations become theoretically more ambiguous.

JEL Code: H25, H26, M52.

Keywords: executive compensation, financial accounting, tax evasion.

\author{
Laszlo Goerke \\ Eberhard Karls University Tübingen \\ Department of Economics \\ Melanchthonstrasse 30 \\ 72074 Tübingen \\ Germany \\ Laszlo.Goerke@uni-tuebingen.de
}

A strictly risk-averse manager makes joint decisions on a firm's tax payments and book profit declarations according to accounting standards. It is analysed how the incentives to overpay or evade taxes and to inflate book profits are influenced by (1) the composition of the manager's remuneration, (2) the ability to control the manager's actions, (3) the costs of making untruthful profit declarations, and (4) the tax rate. If the firm's owner or the government takes into account these effects when pursuing his own objectives, the changes in

I greatly appreciate helpful comments by participants of the CESifo Public Sector conference (München), the annual meetings of the Scottish Economic Society (Perth) and the Verein für Socialpolitik (Bonn), and of seminars at CEU Budapest, LMU München, FU Berlin, JoGU Mainz, and FAU Erlangen-Nürnberg. The paper was completed during a visit to the Department of Finance and Management Science at the Norges Handelshøyskole in Bergen. I would like to thank the NHH for its hospitality. The usual disclaimer applies. 


\section{Introduction}

Recent accounting scandals at large companies such as Enron or Worldcom revealed that false accounting statements have been complemented by incorrect tax declarations in order to increase the credibility of declarations. Such behaviour can also be found in smaller companies. The producer of the 2006 soccer World Cup mascot Nici, for example, had to file for bankruptcy just weeks before the tournament, admitting to having inflated reports on turnover on which taxes had also been paid. Despite this evidence of false statements for tax and accounting purposes, the academic discussion has largely neglected their relationship. Nevertheless, there are obvious trade-offs: a highly profitable company according to financial accounting standards like GAAP is less likely able to claim a small tax base than a less profitable firm. Thus, low book profits can help to hide tax evasion activities. But high book profits may also be attractive since they can, for example, have a positive impact on a manager's share-based remuneration. Hence, high tax payments - or even the over-reporting of tax liabilities - can help to support excessive book profit declarations.

The joint choice of book and tax profit declarations in a world in which tax evasion or tax overpayments can be optimal is investigated below. Related literature is surveyed in Section 2. The model, set up in Section 3, assumes a strictly risk-averse manager whose (indirect) utility is a function of income which, in turn, increases with net profits. If the tax rate is sufficiently low, the gain from excessive tax payments - as higher book profit declarations become feasible surpasses the costs of more taxes due, so that tax overpayments will occur. If the fine for tax evasion is sufficiently high, tax declarations will be truthful and the manager can raise his personal income solely by making excessive book profit declarations. Finally, tax evasion can take place. Section 4 investigates the impact changes in the manager's compensation have on his profit declarations. The analysis, for example, indicates that in countries in which managers are primarily compensated with a fixed salary, the extent of false book profit declarations tends to be less than in countries in which the CEO's compensation is more strongly dependent on profitrelated elements. Section 5 assumes that the firm's owner or the government can anticipate the manager's response to changes in the components of his remuneration and endogenises the respective determinants of the manager's payoff. It then derives the basic features of optimal remuneration contracts (from the owner's perspective) and of optimal government behaviour. Section 5, furthermore, investigates whether the correlation between two now endogenous variables is the same as predicted by the comparative static exercise to gauge the robustness of the predictions derived in Section 4 and of the empirical implications. Section 6 briefly concludes. An appendix contains proofs. 


\section{Literature}

Many investigations of firms' tax evasion behaviour focus on the question of whether evasion decisions can be separated from output choices (Yaniv 1995, Cowell 2004, Goerke and Runkel 2006). The study by Rice (1992) is apparently the only analysis - for a given tax enforcement system - which considers the possibility of insufficient and excessive declarations within the same setting. Rice (1992) assumes that the probability of an audit declines with reported taxable income. If the firm's fixed costs of an audit are sufficiently large, over-reporting of income will occur. ${ }^{1}$ Erickson et al. (2004) provide evidence of such tax overpayments in a sample of 27 firms charged with accounting fraud by the United States Securities and Exchange Commission. Of these firms, 16 paid taxes on overstated earnings "at a mean rate of 19 cents per dollar of pretax earnings overstatement" (p. 5). Furthermore, around 6\% of all corporations in a United States (TCMP) sample over-reported taxable income, while more than two-thirds underreported (Rice 1992).

Another relevant strand of literature focuses on the role of managers in tax evasion decisions. Chen and Chu (2005), for example, examine the incentives for a risk-averse manager to provide (unobservable) effort in a principal-agent setting if the firm's risk-neutral owner can decide to evade taxes but thereby introduces an income risk for the manager. Desai et al. (2007) also investigate the impact of tax evasion opportunities on the divergence of interests between managers and outside shareholders. Their basic point is that income generated by tax evasion activities is easier to hide from outside owners and, hence, more likely to be appropriated by inside managers. Using a principal-agent framework as well, in which a manager decides about corporate tax evasion, Crocker and Slemrod (2005) show that evasion can be deterred more effectively by fines imposed on the manager than on shareholders. Desai and Dharmapala (2006) presume a risk-neutral manager who can evade taxes and divert earnings to increase his personal income. They derive an ambiguous relationship between incentive pay and tax evasion activities, while the results by Hanlon et al. (2007) suggest a positive link.

In addition, there is substantial literature on the incentives to report financial data which do not conform to the information used for making tax declarations. ${ }^{2}$ Shackelford et al. (2007) provide a model in which a company's economic activities and book profit declarations are influenced by

\footnotetext{
${ }^{1}$ Boadway and Sato (2000) look at a world with two income levels in which type I or II errors can occur in the assessment of taxable income. They show that an optimal enforcement system may involve rewards for honest tax payers, so that over-reporting of income by individuals with low incomes can represent equilibrium behaviour.

${ }^{2}$ See Shackelford and Shevlin (2001) for a survey. Desai (2003) finds that "the link between book and tax income has broken down over the last decade" (p. 171) in the United States and indicates that "the distinctive way in which the relationship ... has deteriorated ... is consistent with increased levels of tax sheltering." (p. 200). Manzon and Plesko (2002) and Hanlon and Shevlin (2005) contain further evidence.
} 
accounting regulations and tax laws. However, the investigation of book-tax reporting differences is rarely combined with the issue of false tax declarations. As an exception, Mills and Sansing (2000) construct a game-theoretical model in which the government maximises tax revenues less audit costs, while the firm minimises the difference between tax payments and audit costs. In equilibrium, the audit probability rises with the book-tax difference in expenses. Mills and Sansing (2000) examine United States Internal Revenue Service (IRS) data and find support for their prediction. Mills (1996) shows that the difference between tax payments required by the IRS and actual payments rises with the divergence between accounting and tax data. Hence, the costs of making divergent book-tax declarations seem to increase with the magnitude of differential statements.

Finally, the relationship between incentive pay and false declarations of financial data has been investigated. For example, Goldman and Slezak (2006) set up principal-agent models in which performance-related pay provides incentives for a manager to report earnings fraudulently. The optimal contract includes a lower pay-for-performance sensitivity than its counterpart in a model without the opportunity to deceive. Crocker and Slemrod (2007) characterise the optimal contract for a manager who has private information on the determinants of true profits and can inflate book profits. They also find that some reliance on book profits is optimal.

To sum up: (1) Little attention has been paid to the joint decision about book and (incorrect) tax statements.

(2) Tax evasion and tax overpayments have not been explored in this context.

(3) Over-reporting of tax obligations occurs.

(4) The costs of false statements seem to rise with the difference between financial accounting and tax declarations.

(5) Incentive pay can strengthen the manager's motivation to report earnings fraudulently.

(6) If there are principal-agent conflicts, some reliance of the manager's salary on book profits can be optimal.

\section{Model}

\subsection{Framework}

Consider a firm's single, strictly risk-averse manager who is characterised by von NeumannMorgenstern preferences and the (indirect) utility function $\mathrm{u}, \mathrm{u}^{\prime}>0>\mathrm{u}^{\prime}$. The analysis initially assumes the manager's remuneration system to be given. His income consists of a fixed salary I and a variable, incentive-based component. While a fixed salary generally represents less than 
$50 \%$ of a CEO's pay in the United States, elsewhere the share can be much higher (Murphy 1999, p. 2495). The variable component may include bonuses or stock options. The payment of a bonus is often conditional on the fulfilment of a performance measure. In the present framework, however, true profits $\Pi$ are assumed to be exogenous. They are positive and not perfectly observable to the firm's owner. Accordingly, the incentive-based part of the manager's income depends on true profits $\Pi$ and book profits B, i.e. the (positive) level of profits (before taxes) announced to the public according to financial accounting standards. This specification also concurs with the findings by Crocker and Slemrod (2007) referred to above. The respective weights for true profits and book profits are $\alpha$ and $(1-\alpha), 0<\alpha<1$. The parameter $\alpha$ can then be interpreted to reflect the opportunity of the firm's owner to control the manager's influence on his income. The parameter $\alpha$ is subsequently referred to as the measure of outside control.

The profit-related part of remuneration declines with tax payments $\mathrm{Tt}, \mathrm{t}$ being the tax rate and $\mathrm{T}$ the amount of profits declared to tax authorities. T cannot be negative and can differ from the true level of profits $\Pi$, which also defines tax obligations, because taxes are evaded or overpaid. For simplicity, tax overpayments observed by tax authorities are neither repaid nor penalised. Given a weight $\theta \geq 0$ attached to the profit component, referred to as the indicator of profit dependency, the manager's overall income, whether he does not evade taxes or is not found out doing so, will amount to $\mathrm{y}:=\mathrm{I}+\theta(\alpha \Pi+(1-\alpha) \mathrm{B}-\mathrm{Tt})$. Tax evasion, characterised by $\mathrm{T}<\Pi$, is detected with the (exogenous) probability $1-\mathrm{p}$. In the case of detection, the firm has to pay a fine $\mathrm{Ft}^{\delta}(\Pi-\mathrm{T}), \mathrm{F}>0$ for $\Pi>\mathrm{T}$. The fine is a linear function of taxes evaded $(\delta=1)$ or undeclared profits $(\delta=0)$ and reduces the manager's income according to the indicator of profit dependency $\theta$. Thus, his income equals $\mathrm{y}^{\mathrm{c}}:=\mathrm{I}+\theta\left(\alpha \Pi+(1-\alpha) \mathrm{B}-\mathrm{Tt}-\mathrm{Ft}^{\delta}(\Pi-\mathrm{T})\right){ }^{3}$ In the present setting, if executive compensation depended on pre-tax profits, instead of - at least partly - after-tax profits, there would be no incentives to evade taxes, while tax overpayments could arise. $^{4}$

Tax authorities can be more likely to audit a firm if book profit declarations B exceed the amount of profits announced to tax authorities T. ${ }^{5}$ Alternatively claiming book profits to be greater than taxable profits may alert the firm's owner to excessive profit declarations by the manager. Accordingly, the manager's expected utility is assumed to decline with the difference between

\footnotetext{
${ }^{3}$ Subsequent results are not materially affected by the assumption that a tax or penalty payment of one unit reduces a manager's profit-related income basis by the same amount, as long as a reduced sensitivity to tax payments goes hand in hand with a proportionally lower impact of profits on the manager's income.

${ }^{4}$ Murphy (1999, p. 2501) and Phillips (2003) report for a sample of United States firms that about 60\% (32\%) of CEOs (business-unit managers) have contracts which relate income to after-tax performance measures.

${ }^{5}$ Desai (2003, 2005), Hanlon and Shevlin (2005), Manzon and Plesko (2002), and Plesko (2004), inter alia, provide examples for opportunities to declare divergent book and tax profit levels in the United States.
} 
book profits B and tax profits T. This relationship is consistent with the evidence by Mills (1996) and Mills and Sansing (2000), and is assumed to apply irrespective of whether tax profits T exceed or fall short of true profits П. For simplicity, a linear impact is assumed in which the parameter $\beta$ measures the strength of this effect. Hence, expected utility declines by $\beta(B-T)>0$ for $\mathrm{B}-\mathrm{T}>0$, while $\beta=0$ holds for $\mathrm{B}-\mathrm{T} \leq 0$. This restriction captures the idea that tax profit declarations which equal or exceed book profit statements will not cause any direct utility loss to the manager. Conformity between book and tax declarations does not usually exist and seems undesirable (Hanlon et al. 2005, Hanlon and Shevlin 2005). However, the decisive feature of the model is that any book-tax difference surpassing a threshold - here normalised to zero - is costly. If differential book profit and tax profit declarations are not feasible, because they result in the certain detection of false statements, this restriction requires $B=T$ and $\beta=0$.

Excessive book profit declarations can also be costly for the manager from another perspective. Suppose that the manager is found out to have inflated book profits to boost his own income. Such an action can reduce his future reputation or impair the opportunities to act on behalf of the firm. Alternatively, claiming excessive profits can induce the firm's owner to dismiss the manager, or it can have adverse effects on the manager's future job opportunities. As will be argued below, the existence of positive costs of excessive book profit declarations - relative to true profits - will be a prerequisite for a unique, interior solution to the manager's optimisation exercise if tax overpayments arise. For such a setting only, it is presumed that book profit declarations in excess of true profits reduce expected utility according to a strictly convex, continuous function $\gamma=\gamma(\mathrm{B}-\Pi)$, which implies $\gamma, \gamma^{\prime}, \gamma^{\prime \prime}>(=) 0$ for $\mathrm{B}-\Pi>(\leq) 0$. If there are no tax overpayments $(\Pi \geq \mathrm{T})$, the costs of excessive book profit declarations - relative to true profits - are not required to ensure an interior solution and $\gamma(\bullet)=0$ will be presumed for simplicity.

Denoting the manager's expected utility by $\mathrm{V}$, we can express his objective for $\mathrm{B}>\Pi>\mathrm{T}$ as:

$$
\mathrm{V}=\operatorname{pu}(\underbrace{\mathrm{I}+\theta(\alpha \Pi+(1-\alpha) \mathrm{B}-\mathrm{Tt})}_{:=\mathrm{y}})+(1-\mathrm{p}) \mathrm{u}(\underbrace{\mathrm{I}+\theta\left(\alpha \Pi+(1-\alpha) \mathrm{B}-\mathrm{Tt}-\mathrm{Ft}^{\mathrm{c}}(\Pi-\mathrm{T})\right)}_{:=\mathrm{y}})-\beta(\mathrm{B}-\mathrm{T})
$$

If $\mathrm{B}>\Pi$ and $\mathrm{T} \geq \Pi$, there can be no income variation owing to a penalty payment. For $\mathrm{T}>\Pi$ the costs $\gamma(B-\Pi)$ also need to be incorporated. In the absence of income variations due to uncertainty, $\mathrm{y}^{\mathrm{e}}=\mathrm{y}^{\mathrm{c}}=\mathrm{y}$ holds $($ as $\mathrm{F}=0$ for $\Pi \leq \mathrm{T}$ ), and the manager's objective is given by:

$$
\mathrm{V}=\mathrm{u}(\underbrace{\mathrm{I}+\theta(\alpha \Pi+(1-\alpha) \mathrm{B}-\mathrm{Tt})}_{:=\mathrm{y}})-\beta(\mathrm{B}-\mathrm{T})-\gamma(\mathrm{B}-\Pi)
$$




\subsection{Optimal Choices}

The manager declares taxable profits $\mathrm{T}$ to tax authorities and announces book profits $\mathrm{B}$ to the public. Optimal tax and book profit declarations $\mathrm{B}^{*}$ and $\mathrm{T}^{*}$ can differ and, furthermore, exceed, fall short of, or equal true profits $\Pi$. The ensuing multiplicity of potentially optimal statements can be reduced by taking into account the following observations: firstly, book profit declarations $\mathrm{B}$ which are strictly less than true and tax profits $(\mathrm{B}<\Pi, \mathrm{T})$ cannot be optimal since an increase in B would only raise income. Secondly, a situation in which tax profit statements $\mathrm{T}$ exceed both true and book profits ( $\mathrm{T}>\mathrm{B}, \Pi)$ cannot be optimal either because lowering $\mathrm{T}$ would only reduce costs. Thirdly, truthful declarations $(\Pi=\mathrm{T}=\mathrm{B})$ are irrelevant since we want to analyse the determinants of deviations. Thus, four combinations of profit levels and declarations remain:

Case 1: Tax declarations are truthful while book profits exceed the true level $\left(\mathrm{B}^{*}>\Pi=\mathrm{T}>0\right)$

Case 2: Tax profit statements are excessive but do not surpass book profits $\left(\mathrm{B}^{*} \geq \mathrm{T}^{*}>\Pi>0\right)$

Case 3: Taxes are evaded while book profits exceed tax profit declarations $\left(\mathrm{B}^{*}, \Pi>\mathrm{T}^{*}>0\right)$

Case 4: Taxes are evaded while book profits equal tax profit statements $\left(\Pi>\mathrm{T}^{*}=\mathrm{B}>0\right)$.

Case 2 can only arise if the tax rate $t$ is low, relative to the share of book profits $1-\alpha$, i.e. if $1-\alpha$ $-t>0$. To verify the restriction, suppose otherwise and presume that the manager reduces book and tax profits equally $\left(\mathrm{dB}^{*}=\mathrm{dT}^{*}<0\right)$. The costs of false profit declarations decline since $\mathrm{B}^{*}$ $\Pi>0$ shrinks, while $\mathrm{B}^{*}-\mathrm{T}^{*}$ is held constant by assumption. Moreover, the profit-related component of remuneration $\Delta:=\alpha \Pi+(1-\alpha) \mathrm{B}^{*}-\mathrm{T}^{*} \mathrm{t}>0$ changes by $\mathrm{t}-1+\alpha$ if $\mathrm{B}^{*}$ and $\mathrm{T}^{*}$ decline by the same amount. If $\mathrm{t}-1+\alpha>0$, in contrast to the above restriction, not only the costs of more truthful declarations decline but the gain rises as well. Thus, $\mathrm{B} \geq \mathrm{T}>\Pi$ cannot be optimal and Case 2 can only be sustained for $1-\alpha-t>0$. A similar argument will apply to Cases 3 and 4 if the tax rate is too low and these two settings can, thus, only be optimal for $t>1-\alpha$.

Starting with a marginally positive tax rate $\mathrm{t}(\mathrm{t}>0, \mathrm{t} \rightarrow 0)$, the manager has an incentive to overpay taxes since this is (almost) costless. For low tax rates the manager will, hence, select book and tax profit declarations so as to generate an outcome according to Case 2 - assuming that the costs of false declarations allow for non-truthful statements. Utility $\mathrm{V}$ shrinks with the tax rate, given optimal choices of $\mathrm{B}$ and $\mathrm{T}$, as the application of the envelope theorem to (1') clarifies. If the tax rate $\mathrm{t}$ is greater than a critical value $\mathrm{t}^{*}, 0<\mathrm{t}^{*}<1-\alpha$, the payoff from excessive tax profit declarations will become sufficiently small so that taxes are no longer overpaid. Hence, an outcome according to Case 1 becomes optimal. In this situation, overreporting will be too costly because of the resulting tax payments. Moreover, tax evasion is not beneficial since the costs of excessive book profits fall short of the (expected) costs of under- 
reporting tax obligations. The manager's payoff will also decline with the tax rate $t$ if he selects book profits according to Case 1. If the fine for tax evasion is not too high, the manager will start evading once the tax rate $t$ exceeds a critical value $t^{* *}, 1-\alpha<t^{* *}<1$. Given that the marginal costs $\beta$ of excessive book profits relative to tax profits are not too high, a choice of declarations according to Case 3 maximises the manager's expected utility. Otherwise he is honest with respect to $B$ and an outcome in line with Case 4 occurs. Assuming linear relations and Case 3 to dominate Case 4, the manager's payoffs are depicted as functions of the tax rate $\mathrm{t}$ in Figure $1 .^{6}$

Figure 1: Tax Rate t, Expected Utility V, and Optimal Outcomes

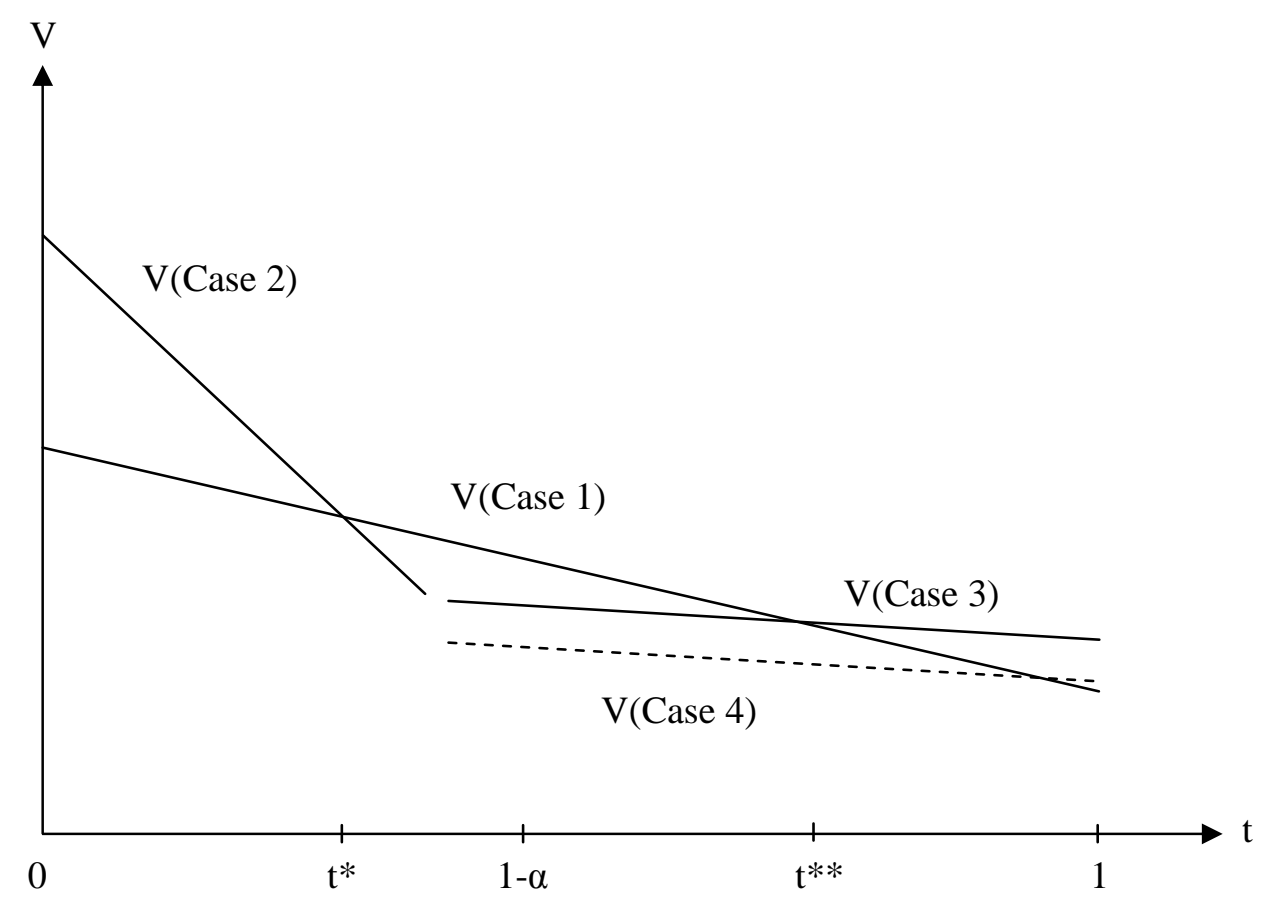

Assuming an interior solution with tax evasion $\left(\mathrm{T}^{*}<\Pi\right)$ and book profits in excess of true profits $\left(\mathrm{B}^{*}>\Pi\right)$, i.e. Case 3 , for which $\gamma(\bullet)=0$ holds, the optimal statements $\mathrm{B}^{*}$ and $\mathrm{T}^{*}$ are defined by:

$$
\begin{aligned}
& \mathrm{V}_{\mathrm{B}}=\theta(1-\alpha)\left[\mathrm{pu}^{\prime}\left(\mathrm{y}^{\mathrm{e}}\right)+(1-\mathrm{p}) \mathrm{u}^{\prime}\left(\mathrm{y}^{\mathrm{c}}\right)\right]-\beta=0 \\
& \mathrm{~V}_{\mathrm{T}}=-\theta\left[\operatorname{pu}^{\prime}\left(\mathrm{y}^{\mathrm{e}}\right) \mathrm{t}+(1-\mathrm{p}) \mathrm{u}^{\prime}\left(\mathrm{y}^{\mathrm{c}}\right)\left(\mathrm{t}-\mathrm{Ft} \boldsymbol{\delta}^{\delta}\right)\right]+\beta=0
\end{aligned}
$$

Relative to a pure tax evasion framework, there is an additional gain from paying taxes in the present setting, as higher tax profits reduce the costs of excessive book profits $\beta(B-T)$. The optimal choice(s) in the other three cases is (are) obtained by maximising $\mathrm{V}$, but focussing on

\footnotetext{
${ }^{6}$ If, for example, tax evasion is penalised more strongly than assumed in Figure $1, \mathrm{t}^{* *}$ will be higher and the payoffs resulting in Cases 3 and 4 may always be less than those in Case 1, so that tax evasion would never arise.
} 
one first-order condition in Cases 1 and 4, and/ or imposing $F=0$ in Cases 1 and 2, and $\beta=0$ in Case 4. Since the second-order conditions vary from case to case, they are dealt with below.

\section{Comparative Statics for Exogenous Remuneration Contract}

How are optimal book and tax profit declarations in the four possible outcomes affected by changes in (1) the indicator of the profit dependency of the manager's income $\theta$, (2) the measure of outside control $\alpha$, (3) the fixed salary I, (4) the marginal costs $\beta$ of making divergent book-tax declarations, and (5) the tax rate t? Exclusively the consequences for local maxima are considered, that is, the order of optimal profit declarations is assumed to be unaffected. Since Case 4 strongly resembles a traditional tax evasion problem, its analysis is kept brief.

\subsection{Case 1: Truthful Tax Declarations And Excessive Book Profits}

Let the manager's profit-related income be denoted by $\theta \Delta(\mathrm{B}, \mathrm{T}), \Delta(\mathrm{B}, \mathrm{T}):=\alpha \Pi+(1-\alpha) \mathrm{B}-\mathrm{tT}$. The manager's behaviour will be governed solely by the first-order condition (2) with respect to the optimal choice of book profits B if, first, the gains from tax evasion are negative, for example, due to a sufficiently high fine $\mathrm{F}$ and, second, an overpayment of taxes is too costly. Given the above assumptions, $\Pi=\mathrm{T}$ and, hence, $\mathrm{y}=\mathrm{I}+\theta((\alpha-\mathrm{t}) \Pi+(1-\alpha) \mathrm{B})=\mathrm{I}+\theta \Delta(\mathrm{B})$ hold. In such a setting, we obtain:

\section{Proposition 1 (Case 1, B* $>\Pi=\mathrm{T}$ )}

If tax profit declarations are truthful $(\mathrm{T}=\Pi)$ and optimal book profits $\mathrm{B}^{*}$ exceed true profits, $\mathrm{B}^{*}$ increases with the tax rate $t$, and will also rise with the indicator of profit dependency $\theta$ if relative risk aversion is less than the ratio of total income y to profit-related income $\theta \Delta(\mathrm{B})$. Optimal book profits $\mathrm{B}^{*}$ decline with the marginal costs $\beta$ of divergent book-tax declarations and the salary $\mathrm{I}$, and will also fall with the measure of outside control $\alpha$ if relative risk aversion is not too high.

\section{Proof: see Appendix 1}

\section{Remarks}

$(\beta, \mathrm{I}, \mathrm{t})$ If the marginal costs $\beta$ of excessive book profits relative to taxable profits rise, the manager will reduce the optimal amount of book profit declarations $B^{*}$ since the utility gain from excessive statements shrinks. An increase in the salary I (a decrease in the tax rate $t$ ) reduces the marginal utility due to the strict concavity of the utility function $u$. Thus, the gain from making excessive declarations declines and optimal book profits fall.

$(\theta, \alpha)$ On the one hand, a greater weight $\theta$ of profits in the manager's remuneration raises marginal utility, so that the incentives to make excessive book profit declarations increase. On 
the other hand, the manager's income rises and marginal utility of income declines. This effect tends to lower book profits. If (relative) risk aversion is not too great, the former impact will dominate the latter and optimal book profit declarations B* will rise. The greater the share is of the salary I in the manager's total remuneration, that is the higher the ratio of total to profitrelated income, the greater relative risk aversion can be, in order for a positive relation between $\theta$ and $\mathrm{B}^{*}$ to exist. This is the case because the rise in income due to a greater weight $\theta$ of profits and the ensuing fall in marginal utility will be small if profits do not affect income by much. Hence, the impact of risk aversion, relative to the direct income effect, does not play a great role.

A shift in the composition of the manager's income, so that a rise in I is compensated by a fall in the parameter $\theta$, holding constant income y for a given value of $\mathrm{B}$, also reduces optimal book profits B*. Hence, the salary effect dominates the consequences of a higher profit dependency.

The reverse intuition as it applies for a rise in the indicator of profit dependency $\theta$ pertains to an increase in the measure of outside control $\alpha$. A rise in $\alpha$ directly reduces the gain from excessive book profits. However, as income falls risk aversion considerations become less important.

\subsection{Case 2: Tax Profit Declarations Are Excessive But Do Not Surpass Book Profit Declarations}

Suppose next, that the manager optimally declares a level of taxable profits $\mathrm{T}^{*}$ which exceeds the true level $\Pi$ but falls (weakly) short of optimal book profits $\mathrm{B}^{*}$. His payoff is certain because only tax evasion is fined, whereas tax overpayments cannot be reclaimed. However, costs $\gamma(\mathrm{B}-\Pi)$ of excessive book profits - relative to true profits - arise. The manager's utility maximum is implicitly defined by:

$$
\begin{gathered}
\mathrm{V}_{\mathrm{B}}=\theta(1-\alpha) \mathrm{u}^{\prime}\left(\mathrm{I}+\theta\left(\alpha \Pi+(1-\alpha) \mathrm{B}^{*}-\mathrm{tT}^{*}\right)\right)-\beta-\gamma^{\prime}\left(\mathrm{B}^{*}-\Pi\right)=0 \\
\mathrm{~V}_{\mathrm{T}}=-\theta \mathrm{tu}^{\prime}\left(\mathrm{I}+\theta\left(\alpha \Pi+(1-\alpha) \mathrm{B}^{*}-\mathrm{tT}^{*}\right)\right)+\beta=0
\end{gathered}
$$

Inspection of equations $\left(2^{\prime}\right)$ and $\left(3^{\prime}\right)$ clarifies that an interior solution $(B \geq T>\Pi)$ can only be assured if a rise in book profits and a fall in tax profit declarations affect utility $\mathrm{V}$ differently. Positive costs $\gamma(\mathrm{B}-\Pi)$ of excessive book profit statements relative to true profits guarantee this requirement. Given a unique interior solution, which requires at least one of the cost functions $\beta$ or $\gamma$ to be strictly convex (see Appendix 2), equations (2') and (3') yield:

Proposition 2 (Case 2, $\mathrm{B}^{*} \geq \mathrm{T}^{*}>\Pi$ )

Assume excessive tax payments and book profit declarations that weakly surpass declared tax profits. Optimal book profits $\mathrm{B}^{*}$ are unaffected by the salary I and the indicator of profit dependency $\theta$. Optimal tax profits $\mathrm{T}^{*}$ increase with the salary $\mathrm{I}$ and change in an ambiguous 
manner with the profit dependency of income $\theta$. An increase in the measure of outside control $\alpha$ and the tax rate $t$ lower optimal book and tax profit statements, while a rise in the marginal costs $\beta$ of making divergent book-tax profit declarations has the reverse impact for $\mathrm{T}^{*}<\mathrm{B}^{*}$.

Proof: see Appendix 2

\section{Remarks}

( $\theta$ ) An increase in the indicator $\theta$ of profit dependency has two effects: firstly, it raises the marginal gains $\mathrm{u}^{\prime}(\mathrm{y}) \theta$ of higher book declarations and tax profit declarations and, thus, requires a larger income y. Secondly, income rises and the marginal utility decreases. The overall impact on tax profit declarations depends on the magnitude of relative risk aversion. It can be noted that any change in income $y$ in response to the increase in $\theta$ affects the manager's choice of book and tax profits equally, with the exception of a constant factor. Since the marginal costs of excessive book profit statements are given by $\gamma^{\prime}(B-\Pi)$ and change with the difference between book and true profits (as $\gamma^{\prime \prime}>0$ ) and because true profits are fixed, book profits must remain the same for the first-order condition (2') to hold. Thus, the entire adjustment in income in response to an increase in $\theta$ is due to the variation in tax profits $\mathrm{T}^{*}$.

( $\alpha$ ) A stronger impact of true profits on the manager's income reduces his incentives to make excessive book profit statements since $\mathrm{B}^{*}>\Pi$. If book profits decline, the gain from overpaying taxes will also shrink. The first-order condition for the optimal choice of tax profits demonstrates that optimal book profits and optimal tax profits have to be adjusted in order to leave overall income y unaffected. Constancy of y implies dy/d $\alpha=\theta\left[\Pi-\mathrm{B}^{*}+(1-\alpha)\left(\partial \mathrm{B}^{*} / \partial \alpha\right)-\mathrm{t}\left(\partial \mathrm{T}^{*} / \partial \alpha\right)\right]=$ 0 . Since $\Pi<\mathrm{B}^{*}, 1-\alpha>\mathrm{t}$, and $\partial \mathrm{B}^{*} / \partial \alpha, \partial \mathrm{T}^{*} / \partial \alpha<0$ hold, tax profit declarations are reduced by more than book profits. Such behaviour is beneficial for the manager since the income gain more than compensates the higher costs of divergent book-tax declarations.

( $\beta$ ) An increase in the marginal costs $\beta$ of making divergent book-tax profit declarations provides an incentive to align book profits $\mathrm{B}^{*}$ and tax profits $\mathrm{T}^{*}$. At first glance it appears as if this can best be achieved by reducing $\mathrm{B}^{*}$ and raising $\mathrm{T}^{*}$. However, such a response would lower the manager's income. To mitigate the fall in income, the manager does not reduce but actually raises optimal book profit declarations $B^{*}$. Since excessive book profits entail marginal costs irrespective of tax profit declarations for $\mathrm{B}^{*}>\Pi$, book profit declarations rise by less than tax profits so that initially $\mathrm{B}^{*}>\mathrm{T}^{*}$ has to hold for the order of profit declarations to be preserved.

(I) The first-order condition (3') for the optimal choice of tax profits $\mathrm{T}^{*}$ shows that a variation in the salary I must be compensated by an adjustment in book profits or in tax profits so that overall income $y$ is unaffected. From the first-order condition (2) for optimal book profits $\mathrm{B}^{*}$ it is 
apparent that a constant income y requires $\mathrm{B}^{*}$ and the marginal costs $\gamma^{\prime}\left(\mathrm{B}^{*}-\Pi\right)$ of excessive book profit statements to be unaffected. Accordingly, tax overpayments $\mathrm{T}^{*}$ have to rise. This is the optimal response to a higher salary I since a decline in book profit declarations by one unit reduces income by 1 - $\alpha$ units, whereas greater tax profits lower income by $\mathrm{t}<1-\alpha$ units.

It is noteworthy that the results relating to an increase in I also hold for a shift in the composition of the manager's income. In particular, a rise in $\mathrm{I}$ is compensated by a fall in the indicator $\theta$ of profit dependency so that income y remains constant, for given values of $\mathrm{B}$ and $\mathrm{T}$.

(t) A higher tax rate $t$ raises the costs of excessive tax payments. Accordingly, overpayments are reduced. This response raises the manager's income for given book profits. ${ }^{7}$ Thus, the marginal (expected) utility of income falls. To bring the gain from excessive book profit declarations into line with the resulting costs, book profits have to fall, but by less than tax profits.

In the set-up outlined in Section 3, the costs of excessive book profit declarations have been modelled in the simplest manner feasible. In particular, a convexity assumption for $\gamma$ has been made to ensure an interior solution (cf. Appendix 2). However, there are neither theoretical arguments nor empirical findings which rule out other functional forms of the cost functions. To evaluate the robustness of Proposition 2, alternatively a linear function $\tilde{\gamma}(B-\Pi), \tilde{\gamma}^{\prime}>(=) 0$, for $\mathrm{B}>(\leq) \Pi, \tilde{\gamma}^{\prime \prime}=0$, and a strictly convex function $\widetilde{\beta}(\mathrm{B}-\mathrm{T}), \widetilde{\beta}^{\prime}, \widetilde{\beta}^{\prime \prime}>(=0)$, for $\mathrm{B}>(\leq) \mathrm{T}$, is presumed. In such a specification, the only unambiguous predictions are $\mathrm{dB} * / \mathrm{d} \tilde{\gamma}, \mathrm{dB} * / \mathrm{dI}$, $\mathrm{dT}^{*} / \mathrm{d} \tilde{\gamma}, \mathrm{dT}^{*} / \mathrm{dI}<0$. Therefore, solely the finding regarding the impact of the salary I on optimal book profits $\mathrm{B}^{*}$ is robust enough to withstand alternative assumptions with respect to the costs of excessive book profit declarations. ${ }^{8}$ The differential results arise because a linear cost function $\beta$ implies that any change in the determinants of the manager's remuneration has to leave his overall income y unaffected, a change in the indicator of profit dependency $\theta$ being the sole exception (cf. equation (3')). However, if the cost function $\gamma$ is linear (and given by $\tilde{\gamma}$ ), this restriction does not arise, so that comparative static results become more ambiguous and are occasionally even reversed.

As an additional check of robustness suppose that differential profit declarations are not feasible because they are infinitely costly, implying $B=T>\Pi$ and $\beta=0$. The effects of variations in the

\footnotetext{
${ }^{7}$ The overall effect of a higher tax rate on tax payments equals $d\left(T^{*} t\right) / d t=u^{\prime}(y)\left(\gamma^{\prime \prime}-\theta^{2}(1-\alpha)^{2} u^{\prime \prime}(y)\right) /\left(\gamma^{\prime \prime} u "(y) \theta t\right)<0$, which can be calculated making use of equation (A.2.8) in Appendix 2.

${ }^{8}$ The computations which prove the findings stated above are analogous to those presented in Appendix 2. An increase in the fixed salary I and a concomitant reduction in the parameter $\theta$, which cancel each other out, so that income y remains constant, have the same qualitative consequences as a sole increase in I.
} 
parameters $\theta, \alpha$, and $t$ depend on the magnitude of the measure of absolute risk aversion. Solely the impact of the salary I is unambiguous, in that a rise in I reduces optimal book profits B*. ${ }^{9}$

\subsection{Case 3: Taxes Are Evaded While Book Profits Exceed Tax Profit Declarations}

Suppose next that taxes are evaded while book profits exceed tax declarations. Book profits can either surpass or fall short of true profits. Since the magnitude of B relative to $\Pi$ has no impact on the results in the case of tax evasion for B $>$ T, given the assumption of $\gamma(\bullet)=0$ for this setup, no further distinction of profit rankings is required. In contrast to Cases 1 and 2, income can vary according to whether tax evasion is detected or not. Thus, optimal behaviour is determined by the first-order conditions (2) and (3) for $\mathrm{y}^{\mathrm{e}}>\mathrm{y}^{\mathrm{c}}$. Formally, the manager's maximisation problem is, thus, similar to that of a tax evading individual who also chooses his working hours.

Proposition 3 (Case 3, B*, П > T*)

Assume that taxes are evaded while book profits exceed tax profit declarations. Optimal book profit declarations $B^{*}$ decline with the salary I and will fall (rise) with the marginal costs $\beta$ of making divergent book-tax profit declarations (the tax rate $\mathrm{t}$ ) if $\mathrm{V}_{\mathrm{TB}} \leq 0$, that is, if absolute risk aversion decreases strongly with income. Tax evasion will fall with the indicator of profit dependency $\theta$ if absolute risk aversion does not decrease with income. Moreover, tax evasion does not change with the salary $I$, and will rise with the tax rate $t$ if the penalty is a function of undeclared income $(\delta=0)$. If $\mathrm{V}_{\mathrm{TB}}<0$ holds, higher marginal costs $\beta$ of divergent profit declarations and a greater measure of outside control $\alpha$ will decrease tax evasion. For $\mathrm{V}_{\mathrm{TB}}>0$, tax evasion will rise with a greater measure of outside control $\alpha$.

Proof: see Appendix 3

\section{Remarks}

$(I, \theta)$ Tax evasion will not be affected by the fixed salary I because the complete adjustment in income required to neutralise the impact of a rise in $\mathrm{I}$ is achieved via a fall in $\mathrm{B}^{*}$. This effect arises since variations in book profits affect both first-order conditions (2) and (3) equally.

A higher profit dependency $\theta$ has a substitution and an income effect. The substitution effect raises tax evasion, for a given amount of book profits, and increases book profits for a given

\footnotetext{
${ }^{9}$ For $\mathrm{B}=\mathrm{T}>\Pi$ and $\beta=0$, equation $\left(2^{\prime}\right)$ defines the optimal selection of $\mathrm{B}$ since $\partial \mathrm{V} / \partial \mathrm{T}<0$ according to $\left(3^{\prime}\right)$. Hence, $\mathrm{B}$ and $\mathrm{T}$ are increased to the same extent beyond $\Pi$ until the gain in income just balances the additional costs captured by $\gamma^{\prime}(B-\Pi)$. Differentiation of (2') for $B=T$ and $1-\alpha-t>0$ yields $V_{B B}, V_{B I}<0$, while the signs of the other derivatives depend on the relation between the first and second derivative of the utility function $\mathrm{u}$.
} 
extent of evasion. The income effect induces adjustments in opposite directions. ${ }^{10}$ Since income declines, constant or increasing absolute risk aversion ensures that tax evasion falls.

If a rise in the salary I is combined with a decline in the indicator of profit dependency $\theta$, holding income constant in both states of the world, for given values of $\mathrm{B}$ and $\mathrm{T}$, optimal tax profits will rise while book profits fall. Therefore, with respect to book profits the impact of a higher salary dominates the effect of a lower indicator of profit dependency, as it is also true for Cases 1 and 2. ( $\beta$ ) Greater marginal costs $\beta$ of making divergent book-tax declarations lower the gain from excessive book and insufficient tax profit statements. Ceteris paribus, book profit declarations and tax evasion decline. However, this potential decline in book profit statements and in the amount of taxes evaded reduces income. For the initial impact to unambiguously dominate the ensuing risk effect, implying that tax evasion $\mathrm{t}\left(\Pi-\mathrm{T}^{*}\right)$ and excessive book profit statements $\mathrm{B}^{*}$ shrink, absolute risk aversion has to strongly decline with income.

( $\alpha$ ) A stronger outside control, as measured by a rise in the parameter $\alpha$, reduces the manager's income, given that book profits exceed the true level. Moreover, the incentives for excessive book profit declarations decline, for a given income, as income and (expected) utility will rise by less with book profits if their relative weight falls. Both effects imply a reduction in income to which the manager will react by raising (reducing) tax evasion if absolute risk aversion does not decrease too much (falls strongly). The change in book profits $B^{*}$ is ambiguous since the fall in income raises the incentives to make excessive declarations, while the smaller impact of book profits on income reduces them.

(t) Basically, the impact of a higher tax rate $t$ on tax evasion will be ambiguous because of the counteracting impact of a higher penalty - if it depends on the amount of taxes evaded - and the substitution impact due to the increase in book profit statements. Therefore, tax evasion will rise if the penalty impact does not occur, i.e. the penalty does not depend on the tax rate and $\delta=0$ holds. Moreover, for a given tax profit declaration, a higher tax rate reduces income so that optimal book profit statements $\mathrm{B}^{*}$ rise. ${ }^{11}$ Apart from this direct positive impact, there is an indirect impact which can work in the opposite direction. This indirect effect occurs due to the substitution effect of a higher tax rate which drives up tax evasion and raises income. If absolute risk aversion rises - or weakly decreases - with income, the manager will counteract this development by decreasing income and book profits. Accordingly, the sign of $\mathrm{dB} * / \mathrm{dt}$ can only be determined if absolute risk aversion strongly decreases with income and will then be positive.

\footnotetext{
${ }^{10}$ See equations (A.3.4) and (A.3.7) in Appendix 3.

${ }^{11}$ This result can be obtained from equations (A.3.1) and (A.3.10) in Appendix 3.
} 


\subsection{Case 4: Taxes Are Evaded While Book Profits Equal Tax Profit Statements}

The first-order condition for a setting in which optimal tax profits coincide with book profit declarations, while both fall short of true profits, is given by equation (3) for $\mathrm{T}^{*}=\mathrm{B}$ since $\beta(B-T)=0$ implies $V_{B}>0$. However, book profits $B$ are not raised beyond $T^{*}$ because this would entail marginal costs $\beta$ assumed to be too high for $\mathrm{B}>\mathrm{T}$ to be optimal. Hence, only an interior solution for tax profit declarations $\mathrm{T}^{*}$ can be achieved. This framework is compatible with the interpretation that divergent profit declarations are not feasible because this would be detected with certainty. Basically, Case 4 resembles a pure tax evasion setting. Thus, the intuition for Proposition 4 is similar to - or the same as - that in a standard tax evasion model à la Allingham and Sandmo (1972) and Yitzhaki (1974), and will not be dwelt upon further.

Proposition 4 (Case 4, $\left.\Pi>\mathrm{T}^{*}=\mathrm{B}\right)$

Suppose that optimal tax profit declarations $\mathrm{T}^{*}$ equal book profits but fall short of true profits. Tax evasion will rise (fall) with the salary I if a manager exhibits decreasing (increasing) absolute risk aversion. Non-increasing absolute risk aversion ensures that tax evasion rises with a greater measure of outside control $\alpha$ and non-decreasing absolute risk aversion guarantees that tax evasion declines with the indicator of profit dependency $\theta$. A higher tax rate $t$ will raise tax evasion if managers exhibit non-decreasing absolute risk aversion and the penalty does not depend on the tax rate $(\delta=0)$.

Proof: Results obtain from equation (3) for $\mathrm{T}^{*}=\mathrm{B}$ and $\beta=0$.

\subsection{Summary}

The comparative static effects derived above are summarised in Tables 1 and 2, assuming constant absolute risk aversion. For Case 2, unambiguous findings are reported only if the impact on $\mathrm{B}^{*}$ and $\mathrm{T}^{*}$ does not depend on the functional form for the costs of excessive declarations (i.e. $\beta$ and $\gamma$ ). Table 1 excludes Case 4 , as it presumes that book profits B cannot vary independently.

Table 1: Impact of an increase in exogenous variables on optimal book profit declaration $\mathrm{B}^{*}$

\begin{tabular}{|l|c|c|c|}
\hline \multicolumn{1}{|c|}{ exogenous variable } & $\begin{array}{c}\text { Case } 1 \\
\mathrm{~B}^{*}>\Pi=\mathrm{T}\end{array}$ & $\begin{array}{c}\text { Case } 2 \\
\mathrm{~B}^{*} \geq \mathrm{T}^{*}>\Pi\end{array}$ & $\begin{array}{c}\text { Case } 3 \\
\mathrm{~B}^{*}, \Pi>\mathrm{T}^{*}\end{array}$ \\
\cline { 1 - 4 }$\theta$ (indicator of profit dependency) & $?$ & $?$ & $?$ \\
\hline$\alpha$ (measure of outside control) & $?$ & $?$ & $?$ \\
\hline $\mathrm{I}$ (fixed salary) & $<0$ & $\leq 0$ & $<0$ \\
\hline$\beta$ (marginal costs of divergent declarations) & $<0$ & $?$ & $?$ \\
\hline $\mathrm{t}$ (tax rate) & $>0$ & $?$ & $?$ \\
\hline
\end{tabular}


Table 1 shows that an increase in the fixed salary I never raises optimal book profit statements $\mathrm{B}^{*}$. Since this is also true for a shift in the composition of income, that is a rise in I and a fall in the indicator of profit dependency $\theta$, the results suggest that in countries or companies in which managers are primarily compensated with a fixed salary the difference between publicly declared book profits $\mathrm{B}^{*}$ and true profits $\Pi$ is less than in settings in which the CEO's compensation is more strongly dependent on profit-related, variable elements.

Table 2 sums up the impact of variations in exogenous variables on the extent of false tax declarations, that is, in Case 2, on the positive and in Cases 3 and 4, on the negative difference between tax and true profits $\mathrm{T}^{*}$ and $\Pi$. Case 1 is excluded as it assumes truthful tax declarations.

Table 2:

Impact of an increase in exogenous variables on optimal extent of false tax declaration $\mathrm{T}^{*}-\Pi$

\begin{tabular}{|l|c|c|c|}
\hline \multicolumn{1}{|c|}{ exogenous variable } & $\begin{array}{c}\text { Case } 2 \\
\mathrm{~B}^{*} \geq \mathrm{T}^{*}>\Pi\end{array}$ & $\begin{array}{c}\text { Case } 3 \\
\mathrm{~B}^{*}, \Pi>\mathrm{T}^{*}\end{array}$ & $\begin{array}{c}\text { Case } 4 \\
\Pi>\mathrm{T}^{*}=\mathrm{B}\end{array}$ \\
\hline$\theta$ (indicator of profit dependency) & $?$ & $<0$ & $<0$ \\
\hline$\alpha$ (measure of outside control) & $?$ & $>0$ & $>0$ \\
\hline $\mathrm{I}$ (fixed salary) & $?$ & 0 & 0 \\
\hline$\beta$ (marginal costs of divergent declarations) & $>0$ for $\mathrm{T}<\mathrm{B}$ & $?$ & n. a. \\
\hline $\mathrm{t}$ (tax rate) & $?$ & $>0$ if $\delta=0$ & $>0$ if $\delta=0$ \\
\hline
\end{tabular}

n. a. - comparative static result is not available as $\mathrm{T}^{*}=\mathrm{B}$ implies $\beta=0$.

Tables 1 and 2 clarify that the relationship between book-tax differences and (a) the determinants of the manager's remuneration, (b) the costs of false profit declarations, and (c) the tax rate is basically uncertain. This ambiguity is due to the fact that optimal tax and book profit statements $\mathrm{B}^{*}$ and $\mathrm{T}^{*}$ both adjust and often do not represent substitutes but tend to move in the same direction.

\section{Endogenising the Remuneration Contract}

The above analysis presumed the remuneration scheme to be given. However, if the manager responds to changes in his income by adjustments in profit declarations, the agents who determine the remuneration contract may use this information to maximise their own payoffs. Assume, therefore, that the components of the manager's gross income are under the control of the firm's owner, while the tax rate $t$ and the marginal costs $\beta$ of divergent profit declarations can be set by the government. The questions then arise whether (1) there is an optimal remuneration system from the owner's or the government's perspective and (2) the comparative static predictions continue to hold. 
To answer these questions, subsequently either the variables controlled by the owner of the firm or the government are endogenised. The timing is as follows: First, the owner (government) chooses fixed income I, the indicator of profit dependency $\theta$, and the measure of outside control $\alpha$ (the tax rate $t$ and the marginal costs $\beta$ of excessive book profit declarations), taking into account that the manager, in a second step, selects profit declarations in order to maximise his expected utility. Accordingly, the owner or the government acts as Stackelberg leader. Their choices and the manager's actions constitute a subgame-perfect equilibrium assumed to be unique and well defined. Finally, it is presumed that the order of profit declarations, as defined by Cases 1 to 4 , remains unaffected.

\subsection{Implications for Optimal Remuneration Contract}

Answering the first of the above questions requires a specification of the objective of the firm's owner and the government. Focussing on the owner's payoff $\Omega$, assume that $\Omega$ is a function of book and tax profits B and T, as well as the components I, $\alpha$, and $\theta$ of the manager's income $\mathrm{y}$. If the owner's payoff declines with the manager's remuneration, $\Omega_{\mathrm{I}}, \Omega_{\theta}<0$ and $\Omega_{\alpha}(\Pi-\mathrm{B})<0$ will apply, where subscripts denote partial derivatives. In addition, higher tax payments make the owner worse off, implying $\Omega_{\mathrm{T}}<0$ for a given tax rate t. Finally, it is likely that the payoff $\Omega$ initially increases with book profits $\mathrm{B}$, for example, because the value of shares rises, but that $\Omega$ eventually declines with $\mathrm{B}$. We will, therefore, have $\Omega=\Omega\left(\mathrm{B}^{*}(\mathrm{z}), \mathrm{T}^{*}(\mathrm{z}), \mathrm{z}\right)$, for $\mathrm{z}=\mathrm{I}, \alpha, \theta$, if the manager chooses B and T optimally. The first-order condition for a maximum of $\Omega$ reads:

$$
\Gamma\left(\mathrm{B}^{*}(\mathrm{z}), \mathrm{T}^{*}(\mathrm{z}), \mathrm{z}\right):=\Omega_{\mathrm{B}} \frac{\mathrm{dB}^{*}}{\mathrm{dz}}+\Omega_{\mathrm{T}} \frac{\mathrm{dT}^{*}}{\mathrm{dz}}+\Omega_{\mathrm{z}}=0
$$

Let the maximisation problem be well behaved, implying $\Omega_{\mathrm{BB}}, \Omega_{\mathrm{TT}}$, and $\Omega_{\mathrm{ZZ}}<0$ inter alia, so that an interior solution is attained, and note that the magnitudes of $\Omega_{\mathrm{B}}$ and $\Omega_{\mathrm{T}}$ cannot be compared, unless $\Omega$ is specified in more detail. An interpretation of (4), therefore, requires knowledge about the signs of $\mathrm{dB} * / \mathrm{dz}$ and of $\mathrm{dT} * / \mathrm{dz}$.

From Tables 1 and 2, dB*/dI $<0$ and $\mathrm{dT}^{*} / \mathrm{dI}=0$ can be established for Cases 1 and 3. Therefore, $\Omega_{\mathrm{T}}, \Omega_{\mathrm{I}}<0$ imply that $\Omega_{\mathrm{B}}<0$ warrants equation (4). For given values of $\theta$ and $\alpha$, the optimal salary I guarantees that the owner's payoff declines with a further rise in book profit declarations. The intuition for $\Omega_{\mathrm{B}}<0$ at $\Gamma(\mathrm{I})=0$ in Cases 1 and 3 is that the optimal salary $\mathrm{I}$ balances the owner's costs due to higher payments to the manager $\left(\Omega_{\mathrm{I}}<0\right)$ with gains resulting from lower book profits $\mathrm{B}^{*}$, which arise since $\mathrm{B}^{*}$ declines with the salary I. 
A complete specification of the manager's optimal remuneration contract, that is an optimal choice of $\mathrm{z}=\mathrm{I}, \alpha, \theta$, is feasible in Case 4 in which the manager only selects the amount of taxes evaded $\Pi-\mathrm{T}^{*}$ optimally. Since $B=\mathrm{T}^{*}, \mathrm{~dB} / \mathrm{dI}=\mathrm{dT}^{*} / \mathrm{dI}=0, \mathrm{~dB} / \mathrm{d} \alpha=\mathrm{dT} * / \mathrm{d} \alpha<0, \mathrm{~dB} / \mathrm{d} \theta=$ $\mathrm{dT}^{*} / \mathrm{d} \theta>0, \Omega_{\mathrm{I}}, \Omega_{\theta}<0$, and $\Omega_{\alpha}<0$ for $\Pi>\mathrm{B}$, we have $\Omega_{\mathrm{I}}<0$ from equation (4). In addition, an interior solution to the maximisation problem with respect to $\theta(\Gamma(\theta)=0)$, given $\Omega_{\mathrm{T}}<0$, requires $\Omega_{\mathrm{B}}>0$. For $\Omega_{\mathrm{B}}>0$, also $\Gamma(\alpha)=0$ is feasible. Given tax evasion and book and tax profits which coincide $\left(\Pi>\mathrm{B}=\mathrm{T}^{*}\right)$, the manager thus receives the lowest fixed salary I feasible $\left(\Omega_{\mathrm{I}}<0\right)$, while his profit-related income is based both on true profits $\Pi$ and on book profit declarations B. The intuition is as follows: In Case 4, the fixed salary I does not influence profit declarations. However, the salary I reduces the owner's payoff $\Omega$ directly. The other two determinants of the manager's remuneration, the indicator of profit dependency $\theta$ and the measure of outside control $\alpha$, both have an indirect impact on the owner's payoff and, hence, also belong to an optimal remuneration scheme.

When interpreting the specification of the manager's optimal remuneration scheme in this manner, a number of caveats should be kept in mind: Firstly, a participation constraint may limit the owner's scope to adjust the fixed salary I downwards. Secondly, since profit declarations depend on $\theta$ and $\alpha$, the optimal choice of $\theta$ and $\alpha$ may yield profit declarations which are no longer compatible with a particular Case, such as Case 4. Thirdly, the components of the manager's remuneration contract have been limited by the definition of income as $y=I+\theta \Delta(T)$. Such a specification may not adequately capture the effects of bonuses or more elaborate compensation schemes. Finally, by assuming a fixed level of true profits $\Pi$, an important element of the owner's payoff has not been endogenised (see e.g. Goldman and Slezak (2006) and Crocker and Slemrod (2007) who focus on this aspect).

\subsection{Implications For Government Policies}

Knowing a manager's response to variations in exogenous parameters may not only stimulate a reaction by the firm's owner but also by the government. Suppose, therefore, that the government optimally determines the variables under its control, namely the tax rate $t$ and the marginal costs $\beta$ of making divergent profit declarations, taking as given the components of the remuneration contract $\mathrm{I}, \alpha$, and $\theta$, and the manager's reactions, as captured by $\mathrm{B}^{*}(\beta, \mathrm{t})$ and $\mathrm{T}^{*}(\beta, \mathrm{t})$. Assume, further, that the government needs tax revenues $\tau>0$. Subject to this constraint $(\tau=\mathrm{Tt})$, the government minimises the sum of the loss arising from divergent book and tax profit declarations $\mathrm{B}-\mathrm{T}$ and the costs $\mathrm{C}$ of reducing this divergence. The government's costs $\mathrm{C}$ increase in the manager's costs $\beta$ of divergent declarations, implying $C=C(\beta), C(0)=0<C^{\prime}, C^{\prime \prime}$. 
To simplify the exposition, the government's loss from divergent declarations is assumed to be a quadratic function of (B - T). Accordingly, the government minimises

$$
\mathrm{G}\left(\mathrm{B}^{*}(\beta, \mathrm{t}), \mathrm{T}^{*}(\beta, \mathrm{t}), \beta, \mathrm{t}\right):=\left(\mathrm{B}^{*}-\mathrm{T}^{*}\right)^{2}+\mathrm{C}(\beta)+\lambda\left[\mathrm{T}^{*} \mathrm{t}-\tau\right]
$$

where $\lambda$ represents the Lagrange-multiplier. The optimisation yields $G_{t}=G_{\beta}=G_{\lambda}=0$.

In Case $4, \mathrm{~T}^{*}=\mathrm{B}$ holds by assumption. Given sufficient tax revenues, the government either sets $\beta$ to the minimal value which just satisfies $\Pi>\mathrm{B}=\mathrm{T}^{*}$ or reduces $\beta$ so that the restrictions of Case 4 no longer apply. Therefore, the comparative static features of Case 4 are not affected by a potential response of the government. Since, moreover, the signs of $\mathrm{dT}^{*} / \mathrm{d} \beta, \mathrm{dB} * / \mathrm{d} \beta, \mathrm{dT} * / \mathrm{dt}$, and $\mathrm{dB} * / \mathrm{dt}$ are at least partially indeterminate in Cases 2 and 3 , the government cannot systematically adjust the tax rate $t$ and the costs $\beta$ of divergent declarations to improve its payoff in these situations.

In Case 1 the manager's response to changes in the indicator of profit dependency $\theta$ and the measure of outside control $\alpha$ are uncertain (see Table 1). Accordingly, the government's optimisation problem is only well-defined in Case 1 with respect to the salary I. Since T is fixed $(\Pi=\mathrm{T}), \mathrm{dT} / \mathrm{dt}=0$ holds by assumption and the tax rate immediately results from the revenue constraint. As a consequence, the government minimises $\mathrm{G}$ exclusively with respect to the costs $\beta$ of divergent declarations. It can then be shown (see Appendix 4) that book profits, taking into account that the government adjusts $\beta$ in response to the manager's behaviour, will decline with the fixed salary I if and only if the third derivative of the utility function is positive $\left(u^{\prime \prime \prime}(y)>0\right)$.

We can conclude: Even if the government knows that a manager responds to variations in the composition of his remuneration, the model does not contain sufficient structure to yield predictions which would let the government condition the tax rate $t$ and the marginal costs $\beta$ of divergent profit declarations on the manager's behaviour. This is the case because, firstly, the relationship between optimal book and tax profit declarations $\mathrm{B}^{*}$ and $\mathrm{T}^{*}$ and the components of the remuneration contract is often not well-defined. Secondly, even if the link is predictable (as in the case of the fixed salary I), the government would have to precisely know the manager's utility function to react optimally.

\subsection{Comparative Statics and Correlations}

The upshot of the previous two sub-sections is that neither the firm's owner nor the government can systematically predict how a manager will react to changes in the components of his remuneration contract. One may therefore conclude that if the owner and the government cannot foresee the consequences of adjustments, for example, in the fixed income I or the tax rate $t$, they 
cannot use the insight of the model to further their own purposes. As a consequence, the comparative static effects summarised in Tables 1 and 2 are unlikely to be affected by taking into account that the indicator of profit dependency $\theta$, the measure of outside control $\alpha$, and the manager's fixed salary I or the tax rate $\mathrm{t}$ and the marginal costs $\beta$ of excessive book profits are effectively endogenous. This conclusion would obviously be strengthened by assuming more sophisticated objectives of the firm's owner and particularly of the government which could, for example, include the revenues resulting from the detection of evasion activities.

However, it may also be contended that particularly the firm's owner and also perhaps the government will be well informed of the manager's behaviour, for example, because the functional relationships (for $\beta(\cdot)$ and $\gamma(\cdot)$ ) and risk attitudes are known. The question then arises whether the comparative static relationships will continue to hold if this knowledge is exploited by the owner and the government. Should the interactions between the various variables predicted on the basis of comparative statics exercises no longer apply, great care will have to be exercised when interpreting evidence in the light of the theoretical analysis.

Given that book and tax profit declarations $\mathrm{B}$ and $\mathrm{T}$ and the components of the remuneration contract $\mathrm{I}, \alpha, \theta$ or the variables $\beta$ and $\mathrm{t}$ under the government's influence are endogenous, the correlation between any two variables may be determined as follows: Suppose, the government is passive. Then, $\mathrm{z}=\mathrm{I}, \alpha, \theta$ are chosen optimally by the owner. A variation either in the tax rate $\mathrm{t}$ or the marginal costs $\beta$ of excessive book profit declarations relative to tax profits can be employed to compute the correlation between $\mathrm{B}^{*}$ and $\mathrm{z}^{*}$. If the direction of this correlation, given by $\mathrm{dB}^{*} / \mathrm{dz}^{*}=(\mathrm{dB} * / \mathrm{dx}) /(\mathrm{dz} / \mathrm{dx})$, for $\mathrm{x}=\mathrm{t}, \beta$, is the same as the comparative static result $\mathrm{dB}^{*} / \mathrm{dz}$ derived in Section 4 , the nature of the link between book profits and the $\mathrm{z}$ variable will not be altered by the endogenisation of $\mathrm{z}$.

To clarify the approach and to derive the scope for results, the subsequent analysis focuses on Case 1, in which tax profit declarations $\mathrm{T}$ are truthful and optimal book profits exceed their true level $\left(\mathrm{B}^{*}>\mathrm{T}=\Pi\right.$ ). In addition, $\mathrm{x}=\mathrm{t}, \beta$ are exogenous. Therefore, the subgame-perfect Nashequilibrium with the firm's owner as a Stackelberg leader is defined by $\mathrm{V}_{\mathrm{B}}\left(\mathrm{B}^{*}, \mathrm{z}, \mathrm{x}\right)=0$ and $\Gamma\left(\mathrm{B}^{*}(\mathrm{z}, \mathrm{x}), \mathrm{T}^{*}(\mathrm{z}, \mathrm{x}), \mathrm{z}, \mathrm{x}\right)=0$ (cf. equations (2) and (4)), for $\mathrm{z}=\mathrm{I}, \alpha, \theta$ (cf. Section 5.1)). Total differentiation of the two equations yields $\mathrm{dB} * / \mathrm{dx}=\left(\Gamma_{\mathrm{X}} \mathrm{V}_{\mathrm{Bz}}-\mathrm{V}_{\mathrm{Bx}} \Gamma_{\mathrm{Z}}\right) / \mathrm{D}$ and $\mathrm{dz}^{*} / \mathrm{dx}=\left(\Gamma_{\mathrm{B}} \mathrm{V}_{\mathrm{Bx}}-\mathrm{V}_{\mathrm{BB}} \Gamma_{\mathrm{X}}\right) / \mathrm{D}$, where the determinant $\mathrm{D}$ and the derivatives $\mathrm{dB} * / \mathrm{dx}$ and $\mathrm{dz} / \mathrm{dx}$ are assumed to be non-zero. Note that $\mathrm{dB} * / \mathrm{dx}$ now describes the adjustment in $\mathrm{B}^{*}$ in the Nashequilibrium defined by equations (2) and (4) and, hence, differs from the expressions derived in Section 4 and used in Sections 5.1 and 5.2. To clarify this difference, let $\mathrm{B}_{\mathrm{Z}}:=-\mathrm{V}_{\mathrm{Bz}} / \mathrm{V}_{\mathrm{BB}}$ and 
$\mathrm{B}_{\mathrm{x}}{ }_{\mathrm{x}}:=-\mathrm{V}_{\mathrm{Bx}} / \mathrm{V}_{\mathrm{BB}}$ denote the (partial) changes in optimal book profits $\mathrm{B}^{*}$, as derived in Section 4 on the basis of equation (2), while $\mathrm{z}^{*}{ }_{\mathrm{X}}=-\Gamma_{\mathrm{X}} / \Gamma_{\mathrm{Z}}$ and $\mathrm{z}^{*} \mathrm{~B}=-\Gamma_{\mathrm{B}} / \Gamma_{\mathrm{Z}}$ represent the optimal (partial) variations in the $\mathrm{z}$ variables (cf. equation (4)). Dividing all expressions of $(\mathrm{dB} * / \mathrm{dx}) /(\mathrm{dz} * / \mathrm{dx})$ by $\mathrm{V}_{\mathrm{BB}} \Gamma_{\mathrm{X}}$, we obtain:

$$
\frac{\mathrm{dB}^{*}}{\mathrm{dz^{* }}}=\frac{\mathrm{z}^{*} \mathrm{~B}_{\mathrm{z}} \mathrm{B}^{*} \mathrm{~B}^{*} \mathrm{x}}{\mathrm{z}^{*} \mathrm{~B}^{\mathrm{B}_{\mathrm{x}}^{*}+\mathrm{z}^{*} \mathrm{x}}}
$$

In Case 1, and given the specification of the government's objective G (cf. equation (5)), the tax rate $t$ is determined by the budget constraint, while the marginal costs $\beta$ of excessive book profits can be chosen optimally by the government. However, from the owner's and the manager's perspective the parameter $\beta$ is exogenous. It can be shown (see Appendix 5) that $\mathrm{z}^{*} \mathrm{~B}^{*} \beta=\mathrm{z}^{*} \beta$. Using this relationship and assuming $\mathrm{x}=\beta$, equation (6) can be rewritten:

$$
2 \frac{\mathrm{dB}^{*}}{\mathrm{dz^{* }}} \mathrm{z}^{*} \beta=\mathrm{B}^{*} \mathrm{z} \mathrm{z}^{*} \beta+\mathrm{B}^{*} \beta
$$

Optimal book profits $\mathrm{B}^{*}$ decrease with the marginal costs $\beta$ of divergent book-tax declarations (see Proposition 1), implying $\mathrm{B}^{*} \beta<0$. The sign of $\mathrm{z}^{*} \mathrm{~B}$ is theoretically ambiguous. In addition, $\mathrm{B}^{*} \mathrm{z}$ can be negative (for $\mathrm{z}=\mathrm{I}$, as well as for $\mathrm{z}=\alpha$ and a measure of relative risk aversion $\Phi=$ $\mathrm{y} /(\theta \Delta(\mathrm{B})))$ or positive (for $\mathrm{z}=\theta$ and $\Phi<\mathrm{y} /(\theta \Delta(\mathrm{B})))$. We, hence, distinguish four cases, resulting from $\mathrm{z}^{*} \beta$ and $\mathrm{B}^{*} \mathrm{z}$ each being either negative or positive. For $\mathrm{B}_{\mathrm{z}} \mathrm{z}^{*} \beta<0$ the right-hand side of (7) is negative and $\mathrm{dB}^{*} / \mathrm{dz}^{*}$ and $\mathrm{B}^{*} \mathrm{z}$ have the same sign. In this case, the correlation between $\mathrm{B}^{*}$ and $\mathrm{z}^{*}$ has the same direction as the change in book profits $\mathrm{B}^{*}$ owing to a rise in an exogenous component $\mathrm{z}$ of the remuneration contract. The endogenisation of the contract and the knowledge about the impact of $\mathrm{z}=\mathrm{I}, \alpha, \theta$ on $\mathrm{B}^{*}$ would not affect the findings derived in Section 4. Suppose, next, that $\mathrm{B}_{\mathrm{z}}^{*}<0$ and $\mathrm{z}^{*} \beta<0$ apply. The first sign restriction holds for $\mathrm{z}=\mathrm{I}$. The second inequality requires an additional restriction on the curvature of $\Omega$. It can then, moreover, be shown that the right-hand side of (7) is negative (see Appendix 5). In such a setting, $\mathrm{dB}^{*} / \mathrm{dz}^{*}$ and $\mathrm{B}_{\mathrm{Z}}$ have opposite signs. $^{12}$

More generally, whether the correlation and the comparative static impact are qualitatively the same depends, inter alia, on the variable which is employed to generate variations in the two endogenous variables, on the specification of the owner's objective $\Omega$, and on the case examined. The intuition for the ambiguous sign of the correlation between the two variables can best be

\footnotetext{
${ }^{12}$ The limiting cases of $\mathrm{z}^{*} \beta=0$, and $\mathrm{B}_{\mathrm{Z}}^{*}=0$ and the combination $\mathrm{B}^{*} \mathrm{z}>0, \mathrm{z}^{*} \beta>0$ are not looked at, since the inequalities considered already suffice to demonstrate that the sign of $(\mathrm{dB} * / \mathrm{dz} *) / \mathrm{B}^{*} \mathrm{z}$ is not well determined
} 
grasped by inspection of equation (7). A change in a variable which is truly exogenous from the manager's and the owner's point of view, also has a direct effect on the respective payoffs. These direct effects are basically of uncertain sign and (relative) magnitude. Therefore, they can not only affect the strength of a relationship between two variables but also alter the direction of the correlation. Only if the change in the exogenous variable $\beta$ had no impact on the manager's behaviour $\left(\mathrm{B}^{*} \beta=0\right)$, would the correlation between $\mathrm{B}^{*}$ and $\mathrm{z}^{*}\left(=\mathrm{I}^{*}\right)$ certainly be of the same direction as suggested by the comparative static exercise.

On an even wider scale, it has to be taken into account that the above analysis has looked at the simplest setting in which the manager only chooses book profit declarations B optimally because tax profits $\mathrm{T}$ coincide with true profits $(\mathrm{T}=\Pi)$. In Cases 2 and 3 the manager can adjust his behaviour at two margins. The analysis of Section 4 has shown that in such a setting the impact of changes in exogenous variables on optimal book profit and tax profit declarations $\mathrm{B}^{*}$ and $\mathrm{T}^{*}$ will become less predictable. This will be all the more true if the determinants of the manager's remuneration contract or the variables under the government's control are endogenous. In addition, if these variables become endogenous, varying a truly exogenous parameter can induce adjustments which move the manager from one case to the other. Accordingly, the main consequences from the findings obtained in Section 5 result for empirical work: In order to assess the validity of the model laid out above, appropriate care has to be taken that truly exogenous changes in the determinants of the manager's utility are examined, or that the endogeneity of the determinants of the manager's payoff is appropriately catered for.

\section{Conclusions}

This paper analyses a risk-averse manager's joint decision regarding tax declarations and book profit statements. Ceteris paribus, tax payments reduce the manager's payoff, while book profits increase it. Tax evasion will be penalised if detected, and excessive book profit declarations can also be costly. In this framework, book profit statements never fall short of true profits and tax profit declarations simultaneously. Moreover, taxes may be overpaid if such behaviour reduces the costs of excessive book profit statements. Tax evasion can also occur.

Four main conclusions derive from the investigation: Firstly, there is a correlation between the tax and book profit declarations which is optimal from a manager's point of view. The theoretical nature of this relationship, that is whether book profit and tax profit declarations are substitutes or complements, depends strongly on the specification of the manager's remuneration contract. Secondly, any empirical investigation of corporate tax compliance and of earnings management has to take into account that variations in exogenous variables likely to affect one indicator of 
management behaviour tend to influence the other as well. Thirdly, interpreting the manager's behaviour within a principal-agent setting, in which either the firm's owner or the government represents the principal, does not provide substantive information regarding the specification of an 'optimal' contract. In addition, variables which are exogenous from the manager's perspective become endogenous in a principal-agent-setting. This can alter the empirically observable correlation between two variables. Fourthly, tax overpayments need not only arise by mistake, but can be an integral component of rational behaviour. 


\section{Appendix}

\section{Proof of Proposition 1 (Case 1, $\mathrm{B}^{*}>\Pi=\mathrm{T}$ )}

The optimal choice of book profit declarations $\mathrm{B}^{*}$ is determined by $\mathrm{V}_{\mathrm{B}}=0$ (cf. equation (2)). Since $\mathrm{V}_{\mathrm{BB}}=\theta^{2}(1-\alpha)^{2} \mathrm{u}^{\prime \prime}(\mathrm{y})<0$ for $\mathrm{T} \geq \Pi$, and $\mathrm{dB}^{*} / \mathrm{dx}=-\mathrm{V}_{\mathrm{Bx}} / \mathrm{V}_{\mathrm{BB}}$ for $\mathrm{x}=\theta, \alpha, \beta, \Pi$, I, the comparative static effects are determined by the signs of $\mathrm{V}_{\mathrm{B} \beta}=-1$ and

$$
\begin{gathered}
\mathrm{V}_{\mathrm{B} \theta}=(1-\alpha)\left[\mathrm{u}^{\prime}(\mathrm{y})+\theta \mathrm{u}^{\prime \prime}(\mathrm{y}) \Delta(\mathrm{B})\right]=(1-\alpha) \mathrm{u}^{\prime}(\mathrm{y})[1-\bar{\varpi}(\mathrm{y})(\theta \Delta(\mathrm{B}) / \mathrm{y})], \\
\mathrm{V}_{\mathrm{B} \alpha}=-\theta\left[\mathrm{u}^{\prime}(\mathrm{y})-\theta(1-\alpha) \mathrm{u}^{\prime \prime}(\mathrm{y})\left(\Pi-\mathrm{B}^{*}\right)\right]=-\theta \mathrm{u}^{\prime}(\mathrm{y})[1-\bar{\varpi}(\mathrm{y})(1-(\mathrm{I}+\theta(\Pi(1-\mathrm{t}))) / \mathrm{y})], \\
\mathrm{V}_{\mathrm{Bt}}=-\theta^{2}(1-\alpha) \mathrm{u}^{\prime \prime}(\mathrm{y}) \mathrm{T}=-\theta \mathrm{TV}_{\mathrm{BI}}>0,
\end{gathered}
$$

for $\Phi(\mathrm{y}):=-\mathrm{yu}^{\prime \prime}(\mathrm{y}) / \mathrm{u}^{\prime}(\mathrm{y})>0$ as the Arrow-Pratt measure of relative risk aversion and $\Delta(\mathrm{B}):=$ $(\alpha-\mathrm{t}) \Pi+(1-\alpha) \mathrm{B}^{*}>0$ for $\Pi=\mathrm{T}$.

\section{Proof of Proposition 2 (Case $2, \mathrm{~B}^{*} \geq \mathrm{T}^{*}>\Pi$ )}

The combination of $\left(2^{\prime}\right)$ and ( $\left.3^{\prime}\right)$ yields $\beta(1-\alpha-t) / t-\gamma^{\prime}\left(B^{*}-\Pi\right)=0$. Thus, $d B^{*} / d I=d B^{*} / d \theta=$ 0 . Total differentiation, moreover, yields:

$$
\frac{\mathrm{dB} *}{\mathrm{~d} \alpha}=-\frac{\beta}{\mathrm{t} \gamma^{\prime \prime}}=\frac{\beta}{\mathrm{t}} \frac{\mathrm{dB} *}{\mathrm{~d} \gamma^{\prime}}=-\frac{\mathrm{dB} *}{\mathrm{~d} \beta} \frac{\beta}{1-\alpha-\mathrm{t}}=\frac{\mathrm{dB} *}{\mathrm{dt}} \frac{\beta \mathrm{t}}{1-\alpha}<0
$$

Differentiation of (3') for $\mathrm{y}=\mathrm{I}+\theta\left(\alpha \Pi+(1-\alpha) \mathrm{B}^{*}-\mathrm{T}^{*} \mathrm{t}\right)=\mathrm{I}+\theta \Delta(\mathrm{B}, \mathrm{T})$ gives rise to

$$
\begin{gathered}
\mathrm{V}_{\mathrm{TB}}=-\theta^{2} \mathrm{u}^{\prime \prime}(\mathrm{y}) \mathrm{t}(1-\alpha)=-\frac{\mathrm{V}_{\mathrm{TT}}(1-\alpha)}{\mathrm{t}}>0, \\
\frac{\mathrm{dT}^{*}}{\mathrm{~d} \theta}=-\frac{\mathrm{V}_{\mathrm{T} \theta}}{\mathrm{V}_{\mathrm{TT}}}=\frac{\mathrm{u}^{\prime}(\mathrm{y})+\theta \mathrm{u}^{\prime \prime}(\mathrm{y}) \Delta(\mathrm{B}, \mathrm{T})}{\theta^{2} \mathrm{u}^{\prime \prime}(\mathrm{y}) \mathrm{t}}=\frac{\mathrm{u}^{\prime}(\mathrm{y})[1-\varpi(\mathrm{y})(1-\mathrm{I} / \mathrm{y})]}{\theta^{2} \mathrm{u}^{\prime \prime}(\mathrm{y}) \mathrm{t}},
\end{gathered}
$$

and

$$
\frac{\mathrm{dT}^{*}}{\mathrm{dI}}=\frac{1}{\theta \mathrm{t}},
$$

as $\mathrm{B}^{*}$ does not change with $\mathrm{I}$ and $\theta$. Taking into account that optimal book profits $\mathrm{B}^{*}$ depend on $\alpha, \gamma^{\prime}, \beta$, and $t$ according to (A.2.1) and (A.2.2), using the results from Appendix 1 gives rise to:

$$
\begin{aligned}
& \frac{\mathrm{dT} *}{\mathrm{~d} \alpha}=-\frac{\mathrm{V}_{\mathrm{T} \alpha}+\mathrm{V}_{\mathrm{TB}} \frac{\mathrm{dB} *}{\mathrm{~d} \alpha}}{\mathrm{V}_{\mathrm{TT}}}=\frac{\gamma^{\prime \prime} \mathrm{t}\left(\Pi-\mathrm{B}^{*}\right)-(1-\alpha) \beta}{\mathrm{t}^{2} \gamma^{\prime \prime}} \\
& \frac{\mathrm{dT} *}{\mathrm{~d} \gamma^{\prime}}=\frac{1-\alpha}{\gamma^{\prime \prime} \mathrm{t}}<0 \\
& \frac{\mathrm{dT} *}{\mathrm{~d} \beta}=\frac{\theta^{2}(1-\alpha) \mathrm{u}^{\prime \prime}(\mathrm{y})[1-\alpha-\mathrm{t}]-\gamma^{\prime \prime}}{\gamma^{\prime \prime} \mathrm{u}^{\prime \prime}(\mathrm{y}) \theta^{2} \mathrm{t}^{2}}>0 \text { since } 1-\alpha-\mathrm{t}>0 \\
& \frac{\mathrm{dT} *}{\mathrm{dt}}=-\frac{\gamma^{\prime \prime} \theta \mathrm{tT}^{*} \mathrm{u}^{\prime \prime}(\mathrm{y})+\mathrm{u}^{\prime}(\mathrm{y})\left(\theta^{2}(1-\alpha)^{2} \mathrm{u}^{\prime \prime}(\mathrm{y})-\gamma^{\prime \prime}\right)}{\gamma^{\prime \prime} \mathrm{u}^{\prime \prime}(\mathrm{y}) \theta \mathrm{t}^{2}}<0
\end{aligned}
$$




\section{Proof of Proposition 3 (Case 3, B* $>\Pi>\mathrm{T}^{*}$ )}

The subsequent calculations are analogous to those in Appendix 2 for $\gamma(B-\Pi)=\gamma^{\prime}=\gamma^{\prime \prime}=0$.

$$
\begin{aligned}
& \mathrm{V}_{\mathrm{BB}}=\theta^{2}(1-\alpha)^{2}\left[\mathrm{pu}^{\prime \prime}\left(\mathrm{y}^{\mathrm{e}}\right)+(1-\mathrm{p}) \mathrm{u}^{\prime \prime}\left(\mathrm{y}^{\mathrm{c}}\right)\right]<0 \\
& \mathrm{~V}_{\mathrm{TT}}=\theta^{2}\left[\mathrm{pu}{ }^{\prime \prime}\left(\mathrm{y}^{\mathrm{e}}\right) \mathrm{t}^{2}+(1-\mathrm{p}) \mathrm{u}^{\prime \prime}\left(\mathrm{y}^{\mathrm{c}}\right)\left(\mathrm{t}-\mathrm{Ft}^{\delta}\right)^{2}\right]<0 \\
& \mathrm{~V}_{\mathrm{TB}}=-\theta^{2}(1-\alpha)\left[\mathrm{pu}^{\prime \prime}\left(\mathrm{y}^{\mathrm{e}}\right) \mathrm{t}+(1-\mathrm{p}) \mathrm{u}^{\prime \prime}\left(\mathrm{y}^{\mathrm{c}}\right)(\mathrm{t}-\mathrm{Ft}\right. \\
&
\end{aligned}
$$

The determinant $\mathrm{D}=\mathrm{V}_{\mathrm{BB}} \mathrm{V}_{\mathrm{TT}}-\left(\mathrm{V}_{\mathrm{BT}}\right)^{2}=\theta^{4}(1-\alpha)^{2} \mathrm{pu}^{\prime \prime}\left(\mathrm{y}^{\mathrm{e}}\right)(1-\mathrm{p}) \mathrm{u}^{\prime \prime}\left(\mathrm{y}^{\mathrm{c}}\right)\left(\mathrm{Ft}^{\delta}\right)^{2}$ is positive $(\mathrm{D}>0)$. Note that by combining (A.3.3) with the first-order condition (3) and using the ArrowPratt-measure of absolute risk aversion $\omega, \omega:=-\mathrm{u}^{\prime \prime}(\mathrm{y}) / \mathrm{u}^{\prime}(\mathrm{y})$, we can relate the sign of $\mathrm{V}_{\mathrm{TB}}$ to $\omega$ :

$$
\mathrm{V}_{\mathrm{TB}}=-\theta^{2}(1-\alpha) \operatorname{ptu}^{\prime}\left(\mathrm{y}^{\mathrm{e}}\right)\left[\omega\left(\mathrm{y}^{\mathrm{c}}\right)\left(1-\frac{\beta}{\theta p u^{\prime}\left(\mathrm{y}^{\mathrm{e}}\right)}\right)-\omega\left(\mathrm{y}^{\mathrm{e}}\right)\right]
$$

If absolute risk aversion does not decrease too strongly with income, $\mathrm{V}_{\mathrm{TB}}>0$ will hold.

Changes in the first-order condition (3) for the optimal choice of tax profit declarations $\mathrm{T}^{*}$, given a positive amount of tax evasion $\left(\mathrm{T}^{*}<\Pi\right)$, are given by $\mathrm{V}_{\mathrm{T} \beta}=1$ and by:

$$
\begin{gathered}
\mathrm{V}_{\mathrm{T} \theta}=-\left[\mathrm{pu}^{\prime}\left(\mathrm{y}^{\mathrm{e}}\right) \mathrm{t}+(1-\mathrm{p}) \mathrm{u}^{\prime}\left(\mathrm{y}^{\mathrm{c}}\right)\left(\mathrm{t}-\mathrm{Ft}^{\delta}\right)\right] \\
-\theta\left[\mathrm{pu}^{\prime \prime}\left(\mathrm{y}^{\mathrm{e}}\right) \mathrm{t} \Delta(\mathrm{B}, \mathrm{T})+(1-\mathrm{p}) \mathrm{u}^{\prime \prime}\left(\mathrm{y}^{\mathrm{c}}\right)\left(\mathrm{t}-\mathrm{Ft}^{\delta}\right)\left(\Delta(\mathrm{B}, \mathrm{T})-\mathrm{Ft}^{\delta}\left(\Pi-\mathrm{T}^{*}\right)\right)\right] \\
=-\frac{\beta}{\theta}+\frac{\Delta(\mathrm{B}, \mathrm{T}) \mathrm{V}_{\mathrm{TB}}}{\theta(1-\alpha)}+\theta(1-\mathrm{p}) \mathrm{u}^{\prime \prime}\left(\mathrm{y}^{\mathrm{c}}\right)\left(\mathrm{t}-\mathrm{Ft}^{\delta}\right) \mathrm{Ft}^{\delta}\left(\Pi-\mathrm{T}^{*}\right) \\
\mathrm{V}_{\mathrm{T} \alpha}=\mathrm{V}_{\mathrm{TI}}\left(\Pi-\mathrm{B}^{*}\right) \theta=\frac{\mathrm{V}_{\mathrm{TB}}\left(\Pi-\mathrm{B}^{*}\right)}{1-\alpha} \\
\mathrm{V}_{\mathrm{Tt}}=-\theta\left[\mathrm{pu}^{\prime}\left(\mathrm{y}^{\mathrm{e}}\right)+(1-\mathrm{p}) \mathrm{u}^{\prime}\left(\mathrm{y}^{\mathrm{c}}\right)\left(1-\delta \mathrm{Ft}^{\delta}-1\right)\right] \\
+\theta^{2}\left[\mathrm{pu}^{\prime \prime}\left(\mathrm{y}^{\mathrm{e}}\right) \mathrm{tT} *+(1-\mathrm{p}) \mathrm{u}^{\prime \prime}\left(\mathrm{y}^{\mathrm{c}}\right)\left(\mathrm{t}-\mathrm{Ft}^{\delta}\right)\left(\mathrm{T}^{*}+\delta \mathrm{Ft}^{\delta-1}\left(\Pi-\mathrm{T}^{*}\right)\right)\right]
\end{gathered}
$$

Note that if $\mathrm{V}_{\mathrm{TB}} \geq 0, \mathrm{~V}_{\mathrm{Tt}}$ will be negative for $\delta=0$. The changes in the first-order condition (2) for the optimal choice of book profit statements $B^{*}$ are determined by $V_{B} \beta=-1$ and:

$$
\begin{aligned}
& \frac{\mathrm{V}_{\mathrm{B} \theta}}{1-\alpha}=\left[\mathrm{pu}^{\prime}\left(\mathrm{y}^{\mathrm{e}}\right)+(1-\mathrm{p}) \mathrm{u}^{\prime}\left(\mathrm{y}^{\mathrm{c}}\right)\right] \\
& +\theta\left[\operatorname{pu}^{\prime \prime}\left(\mathrm{y}^{\mathrm{e}}\right) \Delta(\mathrm{B}, \mathrm{T})+(1-\mathrm{p}) \mathrm{u}^{\prime \prime}\left(\mathrm{y}^{\mathrm{c}}\right)\left(\Delta(\mathrm{B}, \mathrm{T})-\mathrm{Ft}^{\delta}\left(\Pi-\mathrm{T}^{*}\right)\right)\right] \\
& \mathrm{V}_{\mathrm{B} \alpha}=-\theta\left[\operatorname{pu}^{\prime}\left(\mathrm{y}^{\mathrm{e}}\right)+(1-\mathrm{p}) \mathrm{u}^{\prime}\left(\mathrm{y}^{\mathrm{c}}\right)\right]+\theta^{2}(1-\alpha)\left(\Pi-\mathrm{B}^{*}\right)\left[\mathrm{pu}^{\prime \prime}\left(\mathrm{y}^{\mathrm{e}}\right)+(1-\mathrm{p}) \mathrm{u}^{\prime \prime}\left(\mathrm{y}^{\mathrm{c}}\right)\right] \\
& \mathrm{V}_{\mathrm{BI}}=\theta(1-\alpha)\left[\operatorname{pu}^{\prime \prime}\left(\mathrm{y}^{\mathrm{e}}\right)+(1-\mathrm{p}) \mathrm{u}^{\prime \prime}\left(\mathrm{y}^{\mathrm{c}}\right)\right]<0
\end{aligned}
$$




$$
\mathrm{V}_{\mathrm{Bt}}=-\theta^{2}(1-\alpha)\left[\mathrm{pu}^{\prime \prime}\left(\mathrm{y}^{\mathrm{e}}\right) \mathrm{T}^{*}+(1-\mathrm{p}) \mathrm{u}^{\prime \prime}\left(\mathrm{y}^{\mathrm{c}}\right)\left(\mathrm{T}^{*}+\delta \mathrm{t}^{(\delta-1)} \mathrm{F}\left(\Pi-\mathrm{T}^{*}\right)\right)\right]>0
$$

Using (A.3.1) to (A.3.10) and D > 0, the changes in profit declarations equal $\mathrm{dT} * / \mathrm{dI}=0$ and:

$$
\begin{aligned}
& \frac{\mathrm{dT}^{*}}{\mathrm{~d} \theta}=\frac{\theta^{2}(1-\alpha) \mathrm{pu}^{\prime \prime}\left(\mathrm{y}^{\mathrm{e}}\right)(1-\mathrm{p}) \mathrm{u}^{\prime \prime}\left(\mathrm{y}^{\mathrm{c}}\right) \mathrm{Ft}^{\delta}}{\mathrm{D}}\left[\frac{1}{\omega\left(\mathrm{y}^{\mathrm{c}}\right)}-\frac{1}{\omega\left(\mathrm{y}^{\mathrm{e}}\right)}+\theta \mathrm{Ft}^{\delta}\left(\Pi-\mathrm{T}^{*}\right)\right] \\
& \frac{\mathrm{dT}^{*}}{\mathrm{~d} \alpha}=-\mathrm{V}_{\mathrm{TB}} \theta\left[\mathrm{pu}^{\prime}\left(\mathrm{y}^{\mathrm{e}}\right)+(1-\mathrm{p}) \mathrm{u}^{\prime}\left(\mathrm{y}^{\mathrm{c}}\right)\right] / \mathrm{D} \\
& \frac{\mathrm{dT}^{*}}{\mathrm{~d} \beta}=\theta^{2}(1-\alpha) \frac{\mathrm{pu}^{\prime \prime}\left(\mathrm{y}^{\mathrm{e}}\right)(\mathrm{t}-1+\alpha)+(1-\mathrm{p}) \mathrm{u}^{\prime \prime}\left(\mathrm{y}^{\mathrm{c}}\right)\left(\mathrm{t}-\mathrm{Ft}^{\delta}-1+\alpha\right)}{\mathrm{D}} \\
& =-\frac{\mathrm{V}_{\mathrm{TB}}}{\mathrm{D}}-\frac{\theta^{2}(1-\alpha)^{2}\left(p \mathrm{u}^{\prime \prime}\left(\mathrm{y}^{\mathrm{e}}\right)+(1-\mathrm{p}) \mathrm{u}^{\prime \prime}\left(\mathrm{y}^{\mathrm{c}}\right)\right)}{\mathrm{D}} \\
& \frac{\mathrm{dB} *}{\mathrm{~d} \beta}=\frac{\mathrm{V}_{\mathrm{TT}}+\mathrm{V}_{\mathrm{TB}}}{\mathrm{D}}=\frac{\theta^{2}}{\mathrm{D}}\left(\mathrm{pu}^{\prime \prime}\left(\mathrm{y}^{\mathrm{e}}\right) \mathrm{t}(\mathrm{t}-1+\alpha)+(1-\mathrm{p}) \mathrm{u}^{\prime \prime}\left(\mathrm{y}^{\mathrm{c}}\right)\left(\mathrm{t}-\mathrm{Ft}{ }^{\delta}\right)\left(\mathrm{t}-\mathrm{Ft}^{\delta}-1+\alpha\right)\right) \\
& \frac{\mathrm{dB}^{*}}{\mathrm{dI}}=\frac{-\theta^{3}(1-\alpha) \mathrm{pu}^{\prime \prime}\left(\mathrm{y}^{\mathrm{e}}\right)(1-\mathrm{p}) \mathrm{u}^{\prime \prime}\left(\mathrm{y}^{\mathrm{c}}\right)\left(\mathrm{Ft}^{\delta}\right)^{2}}{\mathrm{D}}<0 \\
& \frac{\mathrm{dT}^{*}}{\mathrm{dt}}=\frac{\theta^{4}(1-\alpha)^{2} \mathrm{pu}^{\prime \prime}\left(\mathrm{y}^{\mathrm{e}}\right)(1-\mathrm{p}) \mathrm{u}^{\prime \prime}\left(\mathrm{y}^{\mathrm{c}}\right) \mathrm{Ft}^{\delta} \delta \mathrm{Ft}^{\delta}-1\left(\Pi-\mathrm{T}^{*}\right)}{\mathrm{D}} \\
& +\frac{\theta \mathrm{V}_{\mathrm{BB}}}{\mathrm{D}}\left[\mathrm{pu}^{\prime}\left(\mathrm{y}^{\mathrm{e}}\right)+(1-\mathrm{p}) \mathrm{u}^{\prime}\left(\mathrm{y}^{\mathrm{c}}\right)\left(1-\delta \mathrm{Ft}^{\delta-1}\right)\right]
\end{aligned}
$$

The term in square brackets in the second line of (A.3.16) and of (A.3.17) below is positive, as inspection of the first-order condition (3) reveals. Accordingly, (A.3.16) is negative for $\delta=0$.

$$
\begin{aligned}
& \frac{\mathrm{dB}^{*}}{\mathrm{dt}}=\frac{\theta^{4}(1-\alpha) \mathrm{pu}^{\prime \prime}\left(\mathrm{y}^{\mathrm{e}}\right)(1-\mathrm{p}) \mathrm{u}^{\prime \prime}\left(\mathrm{y}^{\mathrm{c}}\right)\left(\mathrm{Ft}^{\delta}\right)^{2}\left[\mathrm{~T}^{*}+\delta\left(\Pi-\mathrm{T}^{*}\right)\right]}{\mathrm{D}} \\
& -\frac{\mathrm{V}_{\mathrm{TB}} \theta}{\mathrm{D}}\left[\mathrm{pu}^{\prime}\left(\mathrm{y}^{\mathrm{e}}\right)+(1-\mathrm{p}) \mathrm{u}^{\prime}\left(\mathrm{y}^{\mathrm{c}}\right)\left(1-\delta \mathrm{Ft}^{\delta-1}\right)\right]
\end{aligned}
$$

Equations (A.3.12) to (A.3.17) and D > 0 establish Proposition 3. As no unambiguous predictions can be obtained, the derivations of $\mathrm{dB} * / \mathrm{d} \theta$ and $\mathrm{dB} * / \mathrm{d} \alpha$ are omitted.

\section{Optimal Choice of $\beta$ by Government (Case 1)}

For $\mathrm{dT} / \mathrm{dt}=0$ and $\mathrm{t}=\tau / \mathrm{T}, \mathrm{G}$ is given by $\mathrm{G}(\beta)$. Taking into account $\mathrm{dT} * / \mathrm{d} \beta=0$, we have:

$$
\frac{\mathrm{dG}}{\mathrm{d} \beta}:=\mathrm{G}_{\beta}=2\left(\mathrm{~B}^{*}-\mathrm{T}^{*}\right) \frac{\mathrm{dB} *}{\mathrm{~d} \beta}+\mathrm{C}^{\prime}(\beta)=0
$$

Let equation (A.4.1) define the optimal costs $\beta^{*}$ of divergent book and tax profit declarations. Since $\mathrm{G}_{\beta \beta}=2(\mathrm{~dB} * / \mathrm{d} \beta)^{2}>0$ for $\mathrm{d}^{2} \mathrm{~B}^{*} / \mathrm{d} \beta^{2}=0, \mathrm{~dB}^{*} / \mathrm{dI}<0$, and $\mathrm{dB} * / \mathrm{d} \beta=1 /\left(\theta^{2}(1-\alpha)^{2} \mathrm{u}\right.$ (y) $)<0$ for $\mathrm{y}:=\mathrm{I}+\theta\left(\alpha \Pi+(1-\alpha) \mathrm{B}^{*}-\mathrm{Tt}\right)$ (see equation (1') and Appendix 1), the impact of a rise in the fixed salary I on $\beta^{*}$ is given by $d \beta^{*} / d \mathrm{I}=-\left(\mathrm{dG}_{\beta} / \mathrm{dI}\right) / \mathrm{G}_{\beta \beta}$, where $\mathrm{dG}_{\beta} / \mathrm{dI}$ is determined by : 


$$
\frac{\mathrm{dG}_{\beta}}{\mathrm{dI}}=2\left[\frac{\mathrm{dB} *}{\mathrm{dI}} \frac{\mathrm{dB} *}{\mathrm{~d} \beta}-\frac{\left(\mathrm{B}^{*}-\mathrm{T}\right) \mathrm{u}^{\prime \prime \prime}(\mathrm{y})}{\left[\theta(1-\alpha) \mathrm{u}^{\prime \prime}(\mathrm{y})\right]^{2}}\right]
$$

Denoting by $\widetilde{\mathrm{B}}$ optimal book profit declarations in the presence of a government response, making use of (A.4.2) and $\mathrm{dB}^{*} / \mathrm{d} \beta=\mathrm{B}^{*} \beta$, the change in $\widetilde{\mathrm{B}}$ can be calculated as:

$$
\frac{d \tilde{B}}{d I}=\frac{d B^{*}}{d I}+B^{*} \beta \frac{d \beta^{*}}{d I}=\frac{d B^{*}}{d I}-B^{*} \beta \frac{\frac{d B^{*}}{d I} B^{*} \beta-\frac{\left(B^{*}-T\right) u^{\prime \prime \prime}(y)}{\left[\theta(1-\alpha) u^{\prime \prime}(y)\right]^{2}}}{B^{*} \beta B^{*} \beta}=\frac{\left(B^{*}-T\right) u^{\prime \prime \prime}(y)}{B^{*} \beta\left[\theta(1-\alpha) u^{\prime \prime}(y)\right]^{2}}
$$

Since $\mathrm{B}^{*}-\mathrm{T}>0, \mathrm{~d} \widetilde{\mathrm{B}} / \mathrm{dI}$ has the same sign as $\mathrm{dB} * / \mathrm{dI}$ and is, therefore, negative, for $\mathrm{u}^{\prime \prime}(\mathrm{y})>0$.

\section{Correlation: Changes in the Maximised Payoff $\Gamma$ of the Firm's Owner}

The derivatives of $\Gamma$ (cf. equation (4)) with respect to $B, \beta$, and $\mathrm{z}$ are given by:

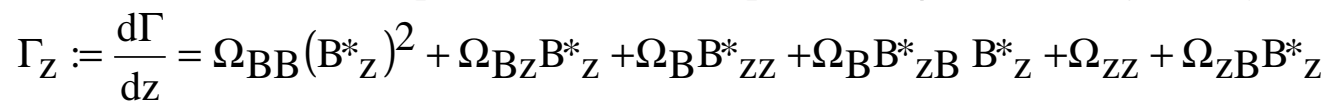

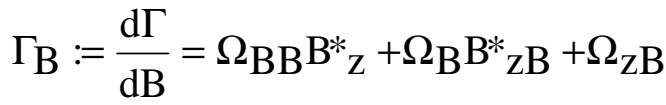

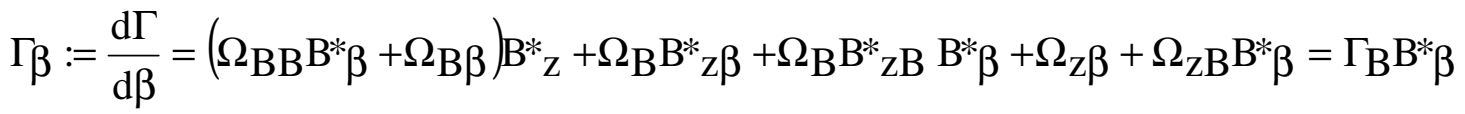

The second-order condition $\Gamma_{\mathrm{Z}}<0$ for a maximum of $\Gamma$ is assumed to hold. Since $\Omega$ and, therefore, also $\Omega_{\mathrm{B}}$ and $\Omega_{\mathrm{Z}}$ are not explicit functions of $\beta, \Omega_{\mathrm{B} \beta}=\Omega_{\mathrm{Z} \beta}=0$ hold. In addition, $\mathrm{V}_{\mathrm{B} \beta}=-1$ implies $\mathrm{B}_{\mathrm{z} \beta}=0$. These considerations establish the relationship between (A5.2) and (A.5.3), as captured by the last equality sign in (A.5.3). For $\mathrm{z}=\mathrm{I}, \mathrm{B}^{*}{ }_{\mathrm{zB}}=0$ applies because $\mathrm{B}^{*} \mathrm{I}$ $=-1 /(\theta(1-\alpha))<0$. Given $\Omega_{\mathrm{BB}}<0$ and $\Omega_{\mathrm{ZB}} \geq 0$ as additional assumption, $\Gamma_{\mathrm{B}}>0$ and $\Gamma_{\beta} \mathrm{B}^{*} \beta<$ 0 result. As a consequence, $\mathrm{z}^{*} \beta<0$ holds. In addition, we have $\mathrm{B}_{\mathrm{II}}=0, \Omega_{\mathrm{II}}<0$, and $\Omega_{\mathrm{IB}} \geq 0$ for $\mathrm{Z}=\mathrm{I}$ and, therefore, obtain:

$$
\mathrm{B}^{*} \mathrm{I}^{\mathrm{I}^{*}} \beta+\mathrm{B}^{*} \beta=-\mathrm{B}^{*} \mathrm{I} \frac{\Gamma_{\beta}}{\Gamma_{\mathrm{I}}}+\mathrm{B}^{*} \beta=\mathrm{B}^{*} \beta \frac{\Omega_{\mathrm{BI} \mathrm{B}^{*} \mathrm{I}}+\Omega_{\mathrm{II}}}{\Gamma_{\mathrm{I}}}<0
$$




\section{References}

Allingham, Michael G. and Agnar Sandmo (1972), Income Tax Evasion: A Theoretical Analysis, Journal of Public Economics 1, 323-338.

Boadway, Robin and Motohiro Sato (2000) The Optimality of Punishing Only the Innocent: the Case of Tax Evasion, International Tax and Public Finance 7, 641-664.

Chen, Kong-Ping and C.Y. Cyrus Chu (2005) Internal Control vs. External Manipulation: a Model of Corporate Income Tax Evasion, RAND Journal of Economics 36, 151-164.

Cowell, Frank A. (2004) Carrots and Sticks in Enforcement, 230-275, in: Aaron, Henry and Joel Slemrod (eds), The Crisis in Tax Administration, Washington DC: Brookings Institution Press.

Crocker, Keith J. and Joel Slemrod (2005) Corporate Tax Evasion with Agency Costs, Journal of Public Economics 89, 1593-1610.

Crocker, Keith J. and Joel Slemrod (2007) The Economics of Earnings Manipulation and Managerial Compensation, RAND Journal of Economics, forthcoming.

Desai, Mihir A. (2003) The Divergence Between Book Income and Tax Income, 169-206, in James Poterba (ed.), Tax Policy and the Economy, Vol. 17, Cambridge (Mass.): The MIT Press.

Desai, Mihir A. (2005) The Degradation of Reported Corporate Profits, Journal of Economic Perspectives 19, 171-192.

Desai, Mihir A., Dyck, Alexander and Luigi Zingales (2007) Theft and Taxes, Journal of Financial Economics 84, 591-623.

Desai, Mihir A. and Dhammika Dharmapala (2006) Corporate Tax Avoidance and High Powered Incentives, Journal of Financial Economics 79, 145-179.

Erickson, Merle, Hanlon, Michelle and Edward Maydew (2004) How Much will Firms Pay for Earnings that Do Not Exist? Evidence of Taxes Paid on Allegedly Fraudulent Earnings, The Accounting Review 79, 387-408.

Goerke, Laszlo and Marco Runkel (2006) Profit Tax Evasion under Oligopoly with Endogenous Market Structure, National Tax Journal 59, 851-857.

Goldman, Eitan and Steve L. Slezak (2006) An Equilibrium Model of Incentive Contracts in the Presence of Information Manipulation, Journal of Financial Economics 80, 603-626.

Hanlon, Michelle, Laplante, Stacie Kelley and Terry Shevlin (2005) Evidence for the Possible Information Loss of Conforming Book Income and Taxable Income, Journal of Law and Economics 48, 407-441.

Hanlon, Michelle and Terry Shevlin (2005) Book-Tax Conformity for Corporate Income: an Introduction to the Issues, 101-134, in James Poterba (ed.), Tax Policy and the Economy, Vol. 19, Cambridge (Mass.): The MIT Press.

Hanlon, Michelle, Mills, Lillian F. and Joel Slemrod (2007) An Empirical Examination of Corporate Tax Noncompliance, 171-220, in Auerbach, Alan J., Hines, James R. and Joel Slemrod (eds), Taxing Corporate Income in the $21^{\text {st }}$ Century, Cambridge eta al.: Cambridge University Press.

Manzon, Gil B. and George A. Plesko (2002) The Relation between Financial and Tax Reporting Measures of Income, Tax Law Review 55, 175-214.

Mills, Lillian F. (1996) Corporate Tax Compliance and Financial Reporting, National Tax Journal 49, 421-435.

Mills, Lillian F. and Richard C. Sansing (2000) Strategic Tax and Financial Reporting Decisions: Theory and Evidence, Contemporary Accounting Research 17, 85-106.

Murphy, Kevin J. (1999) Executive Compensation, 2485-2563, in Ashenfelter, Orley C. and David Card (eds.), Handbook of Labor Economics, Vol. 3B, Amsterdam et al.: Elsevier.

Phillips, John D. (2003) Corporate Tax-Planning Effectiveness: the Role of Compensation-Based Incentives, The Accounting Review 78, 847-874. 
Plesko, George A. (2004) Corporate Tax Avoidance and the Properties of Corporate Earnings, National Tax Journal 57, 729-737.

Rice, Eric M. (1992) The Corporate Tax Gap: Evidence on Tax Compliance by Small Corporations, 125-161, in Slemrod, Joel (ed.), Why People Pay Taxes - Tax Compliance and Enforcement, Ann Arbor: The University of Michigan Press.

Shackelford, Douglas A., Slemrod, Joel and James A. Sallee (2007) A Unifying Model of How the Tax System and Generally Accepted Accounting Principles Affect Corporate Behavior, NBER working paper number 12873.

Shackelford, Douglas A. and Terry Shevlin (2001) Empirical Tax Research in Accounting, Journal of Accounting and Economics 31, 321-387.

Yaniv, Gideon (1995) A Note on the Tax Evading Firm, National Tax Journal 48, 113-120.

Yitzhaki, Shlomo (1974) A Note on Income Tax Evasion: A Theoretical Analysis, Journal of Public Economics 3, 201-202. 


\section{CESifo Working Paper Series}

for full list see www.cesifo-group.org/wp

(address: Poschingerstr. 5, 81679 Munich, Germany, office@cesifo.de)

2148 Andreas Irmen and Rainer Klump, Factor Substitution, Income Distribution, and Growth in a Generalized Neoclassical Model, November 2007

2149 Lorenz Blume, Jens Müller and Stefan Voigt, The Economic Effects of Direct Democracy - A First Global Assessment, November 2007

2150 Axel Dreher, Pierre-Guillaume Méon and Friedrich Schneider, The Devil is in the Shadow - Do Institutions Affect Income and Productivity or only Official Income and Official Productivity?, November 2007

2151 Valentina Bosetti, Carlo Carraro, Emanuele Massetti and Massimo Tavoni, International Energy R\&D Spillovers and the Economics of Greenhouse Gas Atmospheric Stabilization, November 2007

2152 Balázs Égert and Dubravko Mihaljek, Determinants of House Prices in Central and Eastern Europe, November 2007

2153 Christa Hainz and Hendrik Hakenes, The Politician and his Banker, November 2007

2154 Josef Falkinger, Distribution and Use of Knowledge under the "Laws of the Web", December 2007

2155 Thorvaldur Gylfason and Eduard Hochreiter, Growing Apart? A Tale of Two Republics: Estonia and Georgia, December 2007

2156 Morris A. Davis and François Ortalo-Magné, Household Expenditures, Wages, Rents, December 2007

2157 Andreas Haufler and Christian Schulte, Merger Policy and Tax Competition, December 2007

2158 Marko Köthenbürger and Panu Poutvaara, Rent Taxation and its Intertemporal Welfare Effects in a Small Open Economy, December 2007

2159 Betsey Stevenson, Title IX and the Evolution of High School Sports, December 2007

2160 Stergios Skaperdas and Samarth Vaidya, Persuasion as a Contest, December 2007

2161 Morten Bennedsen and Christian Schultz, Arm's Length Provision of Public Services, December 2007

2162 Bas Jacobs, Optimal Redistributive Tax and Education Policies in General Equilibrium, December 2007 
2163 Christian Jaag, Christian Keuschnigg and Mirela Keuschnigg, Pension Reform, Retirement and Life-Cycle Unemployment, December 2007

2164 Dieter M. Urban, Terms of Trade, Catch-up, and Home Market Effect: The Example of Japan, December 2007

2165 Marcelo Resende and Rodrigo M. Zeidan, Lionel Robbins: A Methodological Reappraisal, December 2007

2166 Samuel Bentolila, Juan J. Dolado and Juan F. Jimeno, Does Immigration Affect the Phillips Curve? Some Evidence for Spain, December 2007

2167 Rainald Borck, Federalism, Fertility and Growth, December 2007

2168 Erkki Koskela and Jan König, Strategic Outsourcing, Profit Sharing and Equilibrium Unemployment, December 2007

2169 Egil Matsen and Øystein Thøgersen, Habit Formation, Strategic Extremism and Debt Policy, December 2007

2170 Torben M. Andersen and Allan Sørensen, Product Market Integration and Income Taxation: Distortions and Gains from Trade, December 2007

2171 J. Atsu Amegashie, American Idol: Should it be a Singing Contest or a Popularity Contest?, December 2007

2172 Patricia Apps and Ray Rees, Household Models: An Historical Perspective, December 2007

2173 Ben Greiner, Axel Ockenfels and Peter Werner, The Dynamic Interplay of Inequality and Trust - An Experimental Study, December 2007

2174 Michael Melvin and Magali Valero, The Dark Side of International Cross-Listing: Effects on Rival Firms at Home, December 2007

2175 Gebhard Flaig and Horst Rottmann, Labour Market Institutions and the Employment Intensity of Output Growth. An International Comparison, December 2007

2176 Alexander Chudik and M. Hashem Pesaran, Infinite Dimensional VARs and Factor Models, December 2007

2177 Christoph Moser and Axel Dreher, Do Markets Care about Central Bank Governor Changes? Evidence from Emerging Markets, December 2007

2178 Alessandra Sgobbi and Carlo Carraro, A Stochastic Multiple Players Multi-Issues Bargaining Model for the Piave River Basin, December 2007

2179 Christa Hainz, Creditor Passivity: The Effects of Bank Competition and Institutions on the Strategic Use of Bankruptcy Filings, December 2007 
2180 Emilia Del Bono, Andrea Weber and Rudolf Winter-Ebmer, Clash of Career and Family: Fertility Decisions after Job Displacement, January 2008

2181 Harald Badinger and Peter Egger, Intra- and Inter-Industry Productivity Spillovers in OECD Manufacturing: A Spatial Econometric Perspective, January 2008

2182 María del Carmen Boado-Penas, Salvador Valdés-Prieto and Carlos Vidal-Meliá, the Actuarial Balance Sheet for Pay-As-You-Go Finance: Solvency Indicators for Spain and Sweden, January 2008

2183 Assar Lindbeck, Economic-Social Interaction in China, January 2008

2184 Pierre Dubois, Bruno Jullien and Thierry Magnac, Formal and Informal Risk Sharing in LDCs: Theory and Empirical Evidence, January 2008

2185 Roel M. W. J. Beetsma, Ward E. Romp and Siert J. Vos, Intergenerational Risk Sharing, Pensions and Endogenous Labor Supply in General Equilibrium, January 2008

2186 Lans Bovenberg and Coen Teulings, Rhineland Exit?, January 2008

2187 Wolfgang Leininger and Axel Ockenfels, The Penalty-Duel and Institutional Design: Is there a Neeskens-Effect?, January 2008

2188 Sándor Csengődi and Dieter M. Urban, Foreign Takeovers and Wage Dispersion in Hungary, January 2008

2189 Joerg Baten and Andreas Böhm, Trends of Children's Height and Parental Unemployment: A Large-Scale Anthropometric Study on Eastern Germany, 1994 2006, January 2008

2190 Chris van Klaveren, Bernard van Praag and Henriette Maassen van den Brink, A Public Good Version of the Collective Household Model: An Empirical Approach with an Application to British Household Data, January 2008

2191 Harry Garretsen and Jolanda Peeters, FDI and the Relevance of Spatial Linkages: Do third Country Effects Matter for Dutch FDI?, January 2008

2192 Jan Bouckaert, Hans Degryse and Theon van Dijk, Price Discrimination Bans on Dominant Firms, January 2008

2193 M. Hashem Pesaran, L. Vanessa Smith and Takashi Yamagata, Panel Unit Root Tests in the Presence of a Multifactor Error Structure, January 2008

2194 Tomer Blumkin, Bradley J. Ruffle and Yosef Ganun, Are Income and Consumption Taxes ever really Equivalent? Evidence from a Real-Effort Experiment with Real Goods, January 2008

2195 Mika Widgrén, The Impact of Council's Internal Decision-Making Rules on the Future EU, January 2008 
2196 Antonis Adam, Margarita Katsimi and Thomas Moutos, Inequality and the Import Demand Function, January 2008

2197 Helmut Seitz, Democratic Participation and the Size of Regions: An Empirical Study Using Data on German Counties, January 2008

2198 Theresa Fahrenberger and Hans Gersbach, Minority Voting and Long-term Decisions, January 2008

2199 Chiara Dalle Nogare and Roberto Ricciuti, Term Limits: Do they really Affect Fiscal Policy Choices?, January 2008

2200 Andreas Bühn and Friedrich Schneider, MIMIC Models, Cointegration and Error Correction: An Application to the French Shadow Economy, January 2008

2201 Seppo Kari, Hanna Karikallio and Jukka Pirttilä, Anticipating Tax Change: Evidence from the Finnish Corporate Income Tax Reform of 2005, January 2008

2202 Walter Krämer and André Güttler, On Comparing the Accuracy of Default Predictions in the Rating Industry, January 2008

2203 Syed M. Ahsan and Panagiotis Tsigaris, The Efficiency Loss of Capital Income Taxation under Imperfect Loss Offset Provisions, January 2008

2204 P. Mohnen, F. C. Palm, S. Schim van der Loeff and A. Tiwari, Financial Constraints and other Obstacles: Are they a Threat to Innovation Activity?, January 2008

2205 Sascha O. Becker and Mathias Hoffmann, Equity Fund Ownership and the CrossRegional Diversification of Household Risk, January 2008

2206 Pedro R. D. Bom and Jenny E. Ligthart, How Productive is Public Capital? A MetaAnalysis, January 2008

2207 Martin Werding, Ageing and Productivity Growth: Are there Macro-level Cohort Effects of Human Capital?, January 2008

2208 Frederick van der Ploeg and Steven Poelhekke, Globalization and the Rise of MegaCities in the Developing World, February 2008

2209 Sara Biancini, Regulating National Firms in a Common Market, February 2008

2210 Jin Cao and Gerhard Illing, Liquidity Shortages and Monetary Policy, February 2008

2211 Mathias Kifmann, The Design of Pension Pay Out Options when the Health Status during Retirement is Uncertain, February 2008

2212 Laszlo Goerke, Tax Overpayments, Tax Evasion, and Book-Tax Differences, February 2008 